\title{
Crosstalk between the $\mathrm{M}_{1}$ muscarinic acetylcholine receptor and the endocannabinoid system: A relevance for Alzheimer's disease?
}

\author{
Karen J. Thompson*, Andrew B. Tobin \\ Centre for Translational Pharmacology, Institute of Molecular Cell and Systems Biology, Davidson Building, University of Glasgow, Glasgow G12 8QQ UK
}

\section{A R T I C L E I N F O}

\section{Keywords:}

Alzheimer

Acetylcholine

Cannabinoid

Crosstalk

Cholinergic

Endocannabinoid

\begin{abstract}
A B S T R A C T
Alzheimer's disease (AD) is a neurodegenerative disorder which accounts for $60-70 \%$ of the 50 million worldwide cases of dementia and is characterised by cognitive impairments, many of which have long been associated with dysfunction of the cholinergic system. Although the $\mathrm{M}_{1}$ muscarinic acetylcholine receptor (mAChR) is considered a promising drug target for $\mathrm{AD}$, ligands targeting this receptor have so far been unsuccessful in clinical trials. As modulatory receptors to cholinergic transmission, the endocannabinoid system may be a promising drug target to allow fine tuning of the cholinergic system. Furthermore, disease-related changes have been found in the endocannabinoid system during AD progression and indeed targeting the endocannabinoid system at specific disease stages alleviates cognitive symptoms in numerous mouse models of AD. Here we review the role of the endocannabinoid system in $\mathrm{AD}$, and its crosstalk with mAChRs as a potential drug target for cholinergic dysfunction.
\end{abstract}

\section{Introduction}

50 million people worldwide currently live with dementia and, with an increasingly ageing population, this figure is expected to rise to $>150$ million worldwide by 2050 , becoming the second leading cause of morbidity in the developed world after cancer [1]. The current estimated financial cost of dementia in the United Kingdom is $£ 26.3$ billion per year. Although the National Health Service and social services cover approximately $£ 14.6$ billion of this, some $£ 17.4$ billion two thirds of the total cost - is covered by patients and their families [2]. Of the 50 million worldwide cases of dementia, $60-70 \%$ of these are cases of Alzheimer's disease (AD).

$\mathrm{AD}$ is predominantly associated with memory loss, but symptoms also include agitation, psychosis, depression, apathy, disinhibition, anxiety and sleep disorders [3]. The pathological hallmarks of Alzheimer's disease are brain atrophy and neuroinflammation, which are thought to be largely provoked by the deposition of amyloid-beta (A $\beta$ ) peptide into neuritic plaques and neurofibrillary tangles of tau protein
$[4,5]$ although the role of these is still not entirely understood. However, the cholinergic system has long been implicated in the pathophysiology of $\mathrm{AD}$, as a plethora of cholinergic pathways serving roles in conscious awareness, attention and working memory have been consistently found to be damaged in the brains of those with advanced $\mathrm{AD}$ $[6,7]$. Furthermore, cholinergic transmission is reduced in several key brain regions in $\mathrm{AD}$ including the hippocampus, which is associated with memory formation $[8,9]$. This has resulted in the development of the 'cholinergic hypothesis', which postulates that a loss of cholinergic function in the central nervous system (CNS) significantly contributes to the cognitive decline associated with $\mathrm{AD}$ [10] and, as such, represents a druggable target for $\mathrm{AD}$. Consequently, current $\mathrm{AD}$ treatment strategies focus on improving acetylcholine (ACh) availability. Indeed, currently available drugs for $\mathrm{AD}$ - acetylcholinesterase (AChE) inhibitors - alleviate symptoms by increasing ACh availability in the synaptic cleft of affected brain regions. By augmenting synaptic ACh concentration, $\mathrm{AD}$ symptoms can be relieved and the rate of cognitive decline can be slowed. Although improving ACh availability clearly

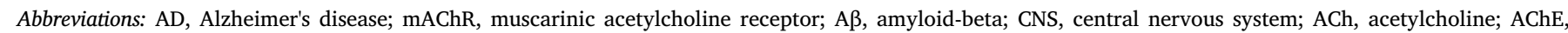

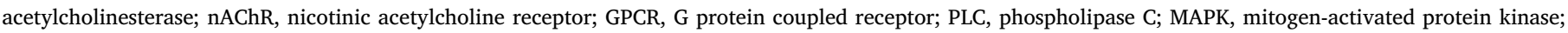

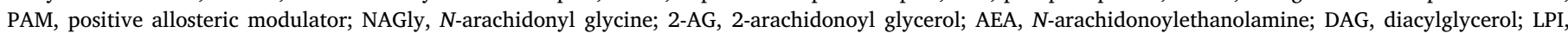

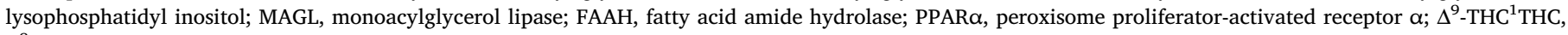

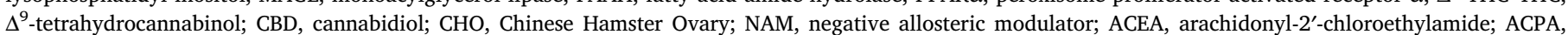

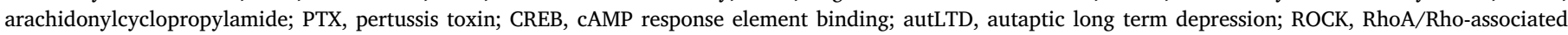
protein protein kinase; EGFP, enhanced green fluorescent protein; APP, amyloid precursor protein; PSEN1, presenilin-1; OP, organophosphorous

* Corresponding author.

E-mail address: karen.thompson.2@glasgow.ac.uk (K.J. Thompson). 
Table 1

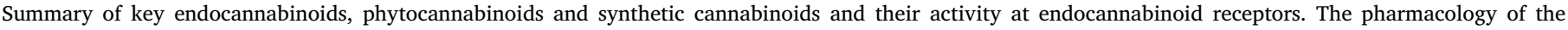
numerous cannabinoids discovered and synthetic cannabinoids now available are extensively reviewed elsewhere (e.g. [67]).

\begin{tabular}{|c|c|c|c|c|}
\hline & Cannabinoid & $\mathrm{CB}_{1}$ activity & $\mathrm{CB}_{2}$ activity & GPR55 activity \\
\hline \multirow[t]{4}{*}{ Endogenous Cannabinoids } & 2-arachidonoyl glycerol (2-AG) & Agonist & Agonist & Agonist \\
\hline & $\mathrm{N}$-arachidonoylethanolamine (anandamide; AEA) & Agonist & Agonist & Agonist \\
\hline & Lysophosphatidyl inositol (LPI) & & & Agonist \\
\hline & $N$-arachidonyl glycine (NAGly) & & & Agonist \\
\hline \multirow[t]{2}{*}{ Phytocannabinoids } & $\Delta^{9}$-tetrahydrocannabinol $\left(\Delta^{9}-\mathrm{THC}^{1} ; \mathrm{THC}\right)$ & Partial Agonist & Partial Agonist & Agonist \\
\hline & Cannabidiol (CBD) & Negative Allosteric Modulator & Partial Agonist & Antagonist \\
\hline \multirow[t]{11}{*}{ Synthetic Cannabinoids } & WIN55,212-2 & Agonist & Agonist & \\
\hline & Arachidonyl-2'-chloroethylamide (ACEA) & Agonist, potent and selective & & \\
\hline & Arachidonylcyclopropylamide (ACPA) & Agonist, potent and selective & & \\
\hline & SR141716a (Rimonabant) & Antagonist & & Antagonist \\
\hline & AM251 & Inverse agonist & & Agonist \\
\hline & JWH-133 & & Agonist & \\
\hline & JWH-015 & & Agonist & Agonist \\
\hline & AM630 & & Antagonist & \\
\hline & SR144528 & & Antagonist & \\
\hline & ML184 & & & Agonist \\
\hline & ML193 & & & Antagonist \\
\hline
\end{tabular}

shows improvements in AD symptoms, AChE inhibitors are nonselective in nature, which renders a myriad of dose-related adverse effects - such as gastrointestinal disturbances and bronchoconstriction [8]. Furthermore, only $30-40 \%$ of patients are responsive to AChE inhibitors [11]. Therefore, the clinical usefulness of AChE inhibitors is limited.

\subsection{Acetylcholine receptors in Alzheimer's disease}

Current research in $\mathrm{AD}$ drug discovery therefore strives to find alternative routes to target the dysregulation of cholinergic signalling. Both nicotinic and muscarinic acetylcholine receptors (nAChRs and mAChRs, respectively) have been implicated in AD. Among the fastacting, channel-forming nAChRs, the $\alpha 7 \mathrm{nAChR}$ is of particular relevance to $\mathrm{AD}$ pathology, given its high expression levels in the hippocampus and physiological role in the enhancement of learning and memory $[12,13]$. Furthermore, $A \beta$ has been shown to enrich in regions abundant in $\alpha 7$ nAChR and elevated levels of the $\alpha 7$ nAChR-A $\beta$ complex are thought to disrupt normal cholinergic signalling, including that involved in synaptic plasticity, ultimately resulting in cognitive dysfunction [12,14,15]. Indeed, administration of $\alpha 7 \mathrm{nAChR}$ agonists AZD0328 and SSR180711 has shown improved cognition in rodents $[16,17]$, and therefore the $\alpha 7$ nAChR undoubtedly represents a promising drug target for $\mathrm{AD}$ treatment. However, the role of $\alpha 7 \mathrm{nAChR}$ in $\mathrm{AD}$ lies beyond the scope of this review, and is more extensively discussed elsewhere.

The mAChRs - of which five subtypes $\left(\mathrm{M}_{1}-\mathrm{M}_{5}\right)$ exist - regulate numerous functions in both the central nervous system and the periphery [18]. mAChRs belong to the Class A G protein coupled receptor (GPCR) superfamily, and are thus large, membrane-bound proteins consisting of 7 transmembrane domains. mAChRs contain an orthosteric binding site, to which endogenous acetylcholine binds, and intracellular regions where interactions with $\mathrm{G}$ proteins take place. Upon agonist binding, the recruitment of $\mathrm{G}$ proteins initiates downstream signalling cascades; $M_{1}, M_{3}$ and $M_{5} m A C h R s$ are coupled to $G \alpha_{q / 11}$ proteins, while $M_{2}$ and $\mathrm{M}_{4}$ mAChRs are coupled to $\mathrm{G} \alpha_{\mathrm{i} / \mathrm{O}}$. The recruitment of $\mathrm{G} \alpha_{\mathrm{q} / 11}$ typically initiates coupling to phospholipase C (PLC), subsequently promoting the release of intracellular calcium $\left(\left[\mathrm{Ca}^{2+}\right]_{\mathrm{i}}\right)$. The release of $\left[\mathrm{Ca}^{2+}\right]_{\mathrm{i}}$ is generally excitatory in nature; for example by facilitating the propagation of neuronal excitation through ion channel opening and the release of neurotransmitters from intracellular vesicles. Meanwhile, $\mathrm{G}_{\mathrm{i}}$ recruitment is inhibitory in nature; agonist binding to $\mathrm{M}_{2}$ and $\mathrm{M}_{4}$ mAChRs results in the downregulation of adenylyl cyclase activity and reduced levels of cyclic adenosine monophosphate (cAMP), while decreasing the activity of voltage-activated $\mathrm{Ca}^{2+}$ channels, and increasing coupling to mitogen-activated protein kinase (MAPK) pathway $[18,19]$.
Of the five mAChR subtypes, $M_{1}$ mAChR is the most abundantly expressed in the brain [20]. Of particular note, $M_{1}$ mAChR has long been implicated in learning and memory in the hippocampus. Recent studies have indicated that $\mathrm{M}_{1} \mathrm{mAChR}$ expression and signalling is maintained in terminal $\mathrm{AD}$ patients [21] suggesting that drugs targeting this receptor subtype will be efficacious even in late disease. Not all studies however support this notion but rather have reported a downregulation of M1 mAChR expression of approximately 50\% in $\mathrm{AD}$ [22]. Encouragingly, activation of this receptor can have pro-cognitive effects, as illustrated by xanomeline, an $\mathrm{M}_{1} / \mathrm{M} 4$-preferring agonist, which elicited significant cognitive and behavioural improvements in AD patients [23]. $M_{1}$ mAChR is thus considered a promising target for the treatment of $\mathrm{AD}$. However, despite such initially promising results, xanomeline ultimately failed in clinical trials due largely to off-target peripheral gastrointestinal and cardiovascular adverse effects thought to be mediated by $\mathrm{M}_{2}$ and $\mathrm{M}_{3} \mathrm{mAChR}$ activation [24]. Indeed, the highly conserved nature of the orthosteric site across all $5 \mathrm{mAChR}$ subtypes has made generating selective muscarinic ligands a challenge that has seriously hampered drug discovery efforts [25]. Efforts to generate selective muscarinic ligands have recently focused on allosteric compounds which target sites which are spatially distinct to the orthosteric binding sites. Allosteric molecules that enhance the activity of the natural ligand acetylcholine - so called positive allosteric modulators (PAMs) - have shown promise by improving both cognitive symptoms and survival in mouse cholinergic-deficit models [26] and in murine prion neurodegeneration [27].

Collectively these studies have provided evidence that the M1 mAChR is a promising molecular target that can not only improve deficits in learning and memory in neurodegenerative disease but also slow the disease progression. This conclusion has encouraged numerous drug discovery efforts that have resulted in clinical studies of both orthosteric [28] as well as allosteric/bitopic ligands [29] which have provided evidence of clinical efficacy, supporting the M1 mAChR as a target in AD.

\section{The endocannabinoid system}

The cannabinoid system encompasses endogenous cannabinoids (endocannabinoids), plant-derived cannabinoids (phytocannabinoids) and their target receptors, all of which are Class A GPCRs. Numerous synthetic cannabinoids are now available for research purposes (Table 1). Cannabinoids have received particular public attention in recent years, with the cannabis-based compound Sativex and the synthetic cannabinoid Nabilone having been legalised for medicinal purposes in the UK since late 2018. However, their prescription under the 
NHS remains restricted.

It was initially believed that the endocannabinoid system only contained two target receptors $-\mathrm{CB}_{1}$ and $\mathrm{CB}_{2}$. However, the recently deorphanised GPR55 is now also considered a cannabinoid receptor, given that - in addition to its endogenous activation by lysophosphatidyl inositol (LPI) and $N$-arachidonyl glycine (NAGly) [30,31] - it is activated by a breadth of endo-, phyto- and synthetic cannabinoids [32-37]. Interestingly, GPR55 has fairly low sequence homology with both $\mathrm{CB}_{1}(13.5 \%)$ and $\mathrm{CB}_{2}(14.4 \%)$ [36,38], and lacks the classical cannabinoid binding pocket expressed by $\mathrm{CB}_{1}$ and $\mathrm{CB}_{2}$ [39], meaning that it is somewhat of an atypical cannabinoid receptor. Collectively, the endogenous ligands, their receptors, and the enzymes which break them down comprise the endocannabinoid system.

\subsection{Endogenous endocannabinoid ligands and their synthesis}

The primary endocannabinoids are 2-arachidonoyl glycerol (2-AG) and $\mathrm{N}$-arachidonoylethanolamine (anandamide; AEA), which both activate $\mathrm{CB}_{1}, \mathrm{CB}_{2}$ and GPR55 with similar efficacy and nanomolar potency [36]. Within the CNS, 2-AG is formed postsynaptically from phosphatidylinositol through the actions of PLC and diacylglycerol (DAG) lipase. Likewise, AEA is produced postsynaptically, but in this case is a downstream product of both phospholipase A2 and PLC [15]. Interestingly, LPI - the primary endogenous ligand for GPR55 - is thought to lie downstream of PLC and DAG formation, meaning that both LPI and 2-AG arise from the same second messenger pathway $[32,40]$. Therefore, the activation of cells via receptors coupled to PLC and PLA2 pathways results in the formation of endocannabinoids. Endocannabinoids are retrograde neurotransmitters; within the CNS, they are released from the postsynaptic neuron into the synaptic cleft and signal in a retrograde manner to endocannabinoid receptors expressed on presynaptic neurons. In this way, endocannabinoid receptors behave as modulators of presynaptic neurotransmitter release.

2-AG and AEA are broken down by monoacylglycerol lipase (MAGL) and fatty acid amide hydrolase (FAAH) respectively [41]. These breakdown enzymes, much like AChE as discussed above, may be exploitable as drug targets in diseases which may benefit from targeting strategies designed to upregulate the endocannabinoid system. This will be discussed in greater detail below.

\subsection{Endogenous cannabimimetics}

AEA is one of many endogenous $N$-acylethanolamine fatty acid amides which are produced concomitantly with AEA, and indeed dihomo- $\gamma$-lonolenic acid, mead acid, and adrenic acid are also capable of binding cannabinoid receptors $[42,43]$. However, the most abundantly produced $N$-acylethanolamines include palmitoylethanolamide and stearoylethanolamide, which do not bind cannabinoid receptors. Instead, a role for palmitoylethanolamide in anti-inflammatory, analgesic, anti-epileptic and neuroprotective functions is thought to be mediated at least in part by the peroxisome proliferator-activated receptor $\alpha$ (PPAR $\alpha)[44,45]$. Indeed, palmitoylethanolamide has been suggested as therapeutically useful across a breadth of pathologies, including neurodegeneration (reviewed in [46]). Meanwhile, $N$-stearoylethanolamide treatment prevented the loss of $\alpha 7 \mathrm{nAChRs}$ and the accumulation of pathogenic $A \beta$ bound to $\alpha 7$ nAChRs in the brains of mice treated with bacterial lipopolysaccharide, which otherwise exhibit $\alpha 7 \mathrm{nAChR}$ loss and pathogenic $\mathrm{A} \beta$ binding to $\alpha 7 \mathrm{nAChR}$ accumulation [47]. Furthermore, $N$-stearoylethanolamide improved episodic memory in these mice, indicating treatment with $N$-stearoylethanolamide demonstrates a therapeutic potential for the prevention of cognitive dysfunction caused by neuroinflammation such as that seen in AD.

Many $N$-acylethanolamines concomitantly produced with AEA including pamitoylethanolamide and $N$-stearoylethanolamide, as discussed above - are more abundant in most animal tissues than AEA. It has therefore been recently speculated that the release of such $N$ - acylethanolamines could be the primary downstream products of the pathways producing AEA (reviewed in [48]). The potential therapeutic benefits of the $\mathrm{N}$-acylethanolamines for neurodegenerative diseases, as briefly outlined above, are of importance when considering targeting the endocannabinoid system. However, more in-depth research is required in order to fully elucidate the druggable potential of the cannabimimetic $N$-acylethanolamines.

\subsection{Phytocannabinoids}

Phytocannabinoids have been used for recreational and therapeutic purposes for thousands of years [49], but have been of particular public interest in recent years given numerous emerging reports of the therapeutic potential in otherwise uncontrolled epilepsy, pain disorders, emesis and multiple sclerosis-related spasticity. To date, over 100 phytocannabinoids falling into eleven different chemical classes have been identified. All phytocannabinoid classes and their purported actions are reviewed extensively elsewhere [49,50]. Of importance, however, are the $\Delta^{9}$-tetrahydrocannabinol $\left(\Delta^{9}-\right.$ THC $^{1}$; THC) and cannabidiol (CBD) classes, which are typically the two most abundant phytocannabinoids in Cannabis sativa respectively [50,51]. While THC is the main psychoactive component of cannabis, CBD retains the analgesic and anti-inflammatory properties of cannabis while being devoid of psychotropic effects.

THC is a partial agonist at both $\mathrm{CB}_{1}$ and $\mathrm{CB}_{2}$, with similar binding affinity at both receptors in AtT-20 [52] and Chinese Hamster Ovary (CHO) [53] cell lines. However, a modest reduction in THC potency for $\mathrm{CB}_{2}$ in comparison to $\mathrm{CB}_{1}$ was seen in the inhibition of forskolin-stimulated cAMP accumulation [52]. The characteristics of THC at the $\mathrm{CB}_{1}$ receptor have been paralleled to those of anandamide in terms of affinity, partial agonism and lower efficacy at $\mathrm{CB}_{2}$ in vitro [54]. Meanwhile, THC acts as a full agonist at GPR55, with nanomolar potency in a GTP $\gamma$ S assay [36].

In contrast to THC, $\mathrm{CBD}$ appears to act as a negative allosteric modulator (NAM) at the $\mathrm{CB}_{1}$ receptor. The affinity for $\mathrm{CBD}$ is reportedly very low, with a meta-analysis indicating a $\mathrm{K}_{\mathrm{i}}$ of $3245 \mathrm{nM}$ for $\mathrm{CBD}$ at the $\mathrm{CB}_{1}$ orthosteric site [55]. However, submicromolar concentrations of CBD were sufficient to inhibit internalisation of endogenously expressed $\mathrm{CB}_{1}$ in the $\mathrm{STHdh} h^{\mathrm{Q7} / \mathrm{Q} 7}$ cell culture model of striatal medium spiny projection neurons [56], suggesting that $\mathrm{CBD}$ is capable of affecting $\mathrm{CB}_{1}$ signalling at concentrations lower than those required for orthosteric binding. Indeed, the affinity of $\mathrm{CBD}$ to the allosteric binding site $\left(\mathrm{K}_{\mathrm{B}}\right)$ on $\mathrm{CB}_{1}$ has been found to be between 270 and $352 \mathrm{nM}$ in HEK293 cells, and between 278 and $333 \mathrm{nM}$ in STHdh ${ }^{\text {Q7/Q7 }}$ cells [57]. A degree of functional selectivity was seen in STHdh ${ }^{\mathrm{Q7} / \mathrm{Q} 7}$ (but not HEK293) cells, but importantly CBD reduced the potency and efficacy of both THC and 2-AG in both of these cell lines [57,51]. Meanwhile at the $\mathrm{CB}_{2}$ receptor, $\mathrm{CBD}$ is an orthosteric partial agonist, capable of competing with the synthetic $\mathrm{CB}_{2}$ receptor agonist SR144528 [51]. Finally, CBD is a competitive antagonist of GPR55 [36,51], and is also capable in vitro of anandamide uptake inhibition, thus increasing endocannabinoid availability [58,59]. Indeed, this may well explain some of the reported therapeutic effects of $\mathrm{CBD}$, given that the uptake mechanisms of anandamide and 2-AG are potential therapeutic targets, as discussed in detail below.

In addition to their activity at their putative endocannabinoid receptors, both THC and CBD modulate the activity of numerous additional cellular effectors. For example, THC has been found to inhibit $5 \mathrm{HT}_{3 \mathrm{~A}}$-induced currents in HEK293 cells and cultured rat trigeminal ganglion neurons $[60,61]$, while potentiating positive allosteric modulatory effects at TRPA1 [62] and TRPV2 [63]. Meanwhile, CBD also modulates $5 \mathrm{HT}_{1 \mathrm{~A}}$ [64], GPR55 [36], $\mu$ - and $\delta$-opioid receptors [65], TRPV1 channels [58], and PPAR $\gamma$ [66]. Therefore, when considering the therapeutic potential of cannabinoids, such off-target activity must be borne in mind. Given that the proportion of each chemical class dependent on numerous aspects such as the strain of the plant, growing 
conditions, and processing methods - varies enormously, this can produce substantial pharmacological variations in Cannabis sativa. It is thus crucial to fully understand the pharmacological properties of each of the phytocannabinoids to exploit their potential, and the potential of the endocannabinoid system as a druggable target.

\subsection{Synthetic cannabinoids}

The discovery of the endocannabinoid system was soon followed by the production of numerous synthetic cannabinoid compounds in a bid to advance research and understanding around the endocannabinoid system and its potential for therapeutic exploitation. A plethora of such synthetic compounds now exists, and are extensively reviewed elsewhere (e.g. [67]). A summary of key synthetic compounds now widely used in research is provided in Table 1.

The highly potent, yet nonselective, CB agonist WIN55,212-2 (WIN55212) was first synthesised in 1992 [68]. This analogue of pravadoline exerts full agonism at both the $\mathrm{CB}_{1}[52,53,69]$ and $\mathrm{CB}_{2}$ receptors [70]. However, it is noteworthy that WIN55212 has higher affinity and efficacy at $\mathrm{CB}_{2}$ than $\mathrm{CB}_{1}$ [52] and, importantly, has neither binding nor functional activity at GPR55 [36].

Arachidonyl-2'-chloroethylamide (ACEA) and arachidonylcyclopropylamide (ACPA), first synthesised in 1999, are both analogues of AEA and are potent, selective agonists of the $\mathrm{CB}_{1}$ receptor [71]. Both of these compounds bind $\mathrm{CB}_{1}$ receptors with higher affinity than $\mathrm{AEA}$, and inhibit forskolin-stimulated adenylyl cyclase activity in cells expressing the $\mathrm{CB}_{1}$ receptor, but not in cells expressing the $\mathrm{CB}_{2}$ receptor [71]. Rimonabant - SR141716a - is a selective antagonist for $\mathrm{CB}_{1}$ receptors, able to antagonise the effects of both anandamide and WIN55212, and is thus a competitive antagonist at the $\mathrm{CB}_{1}$ receptor [52,72]. Rimonabant was approved as an antiobesity drug in the EU in 2006, but was withdrawn from use in the $\mathrm{EU}$ in 2008 due to serious psychiatric adverse effects, including suicide. However, SR141716a remains widely used for research, along with the structurally similar AM251 which acts as a potent inverse agonist at $\mathrm{CB}_{1}$ receptors, to allow dissection of $\mathrm{CB}_{1}$ and $\mathrm{CB}_{2}$ receptor activity.

First synthesised in 1999, JWH-133 is a THC analogue which is a highly selective, full agonist for $\mathrm{CB}_{2}$ [73]. Excitingly, this synthetic cannabinoid has been shown to reduce spasticity in a murine model of multiple sclerosis [74], thus highlighting the therapeutic potential of selective synthetic cannabinoids. JWH-015 is also a selective $\mathrm{CB}_{2}$ agonist which is widely used to date for $\mathrm{CB}_{2}$ research [75,53]. In terms of antagonists, both AM630 and SR144528 are more potent at blocking $\mathrm{CB}_{2}$ activity over $\mathrm{CB}_{1}$ activity, exhibit higher affinity for $\mathrm{CB}_{2}$, and block agonist-induced $\mathrm{CB}_{2}$ activation in a competitive manner [67].

The activity of synthetic cannabinoids at GPR55 has yielded some surprising results. Both the $\mathrm{CB}_{2}$ agonist JWH015 and the $\mathrm{CB}_{1}$ antagonist AM251 evoke an increase in intracellular calcium in HEK293 cells expressing GPR55 [76]. Meanwhile, GPR55 is unresponsive to the nonselective $\mathrm{CB}$ agonist WIN55212, yet the $\mathrm{CB}_{1}$ antagonist SR141716a is also an antagonist at GPR55 [76]. Lastly, some selective synthetic cannabinoids now exist for GPR55 - ML184 is a potent and selective agonist at this receptor [34], while ML193 is a potent and selective antagonist [77].

\section{3. $\mathrm{CB}_{1}$ and $\mathrm{CB}_{2}$ Receptors - the classical cannabinoid receptors}

The $\mathrm{CB}_{1}$ receptor, first cloned in 1990 [78], are widely expressed in the central nervous system within both neurons and glial cells, where they are predominantly expressed at the terminals of neurons. Here, they serve as modulators of both excitatory and inhibitory neurotransmission, and mediate numerous brain functions including cognition [79]. Furthermore, $\mathrm{CB}_{1}$ activity protects against excitotoxicity and promotes repair mechanisms in response to neuronal damage [41].

Cloning of the $\mathrm{CB}_{2}$ receptor followed soon after in 1993 [70]. Its expression is classically associated with the periphery where it is largely implicated in immune functions [80], and is responsible for the antiinflammatory effects of cannabis [81]. In peripheral immune cells, such as B lymphocytes, natural killer cells, monocytes, macrophages, microglia and T lymphocytes [80], $\mathrm{CB}_{2}$ is thought to modulate cell migration and cytokine release. $\mathrm{CB}_{2}$ is also found on microglial cells - the resident immune cells of the brain [82] - yet is barely detectable in the healthy brain [83]. However, evidence for neuronal $\mathrm{CB}_{2}$ expression in the hippocampus, and a resulting role in synaptic plasticity, has recently been described [81]. Furthermore, $\mathrm{CB}_{2}$ levels in the brain have been shown to be elevated in response to neuroinflammation and CNS damage, indicating a far more prominent role for $\mathrm{CB}_{2}$ in the CNS than originally believed (see discussion below).

Both $\mathrm{CB}_{1}$ and $\mathrm{CB}_{2}$ signal predominantly through $\mathrm{G \alpha}_{\mathrm{i}} /$ o proteins, and thus in a manner similar to $\mathrm{M}_{2}$ and $\mathrm{M}_{4}$ mAChRs, inhibit adenylyl cyclase but have also been reported to increase activation of the MAPK pathway [41], inhibit voltage-dependent $\mathrm{Ca}^{2+}$ channels, and activate $\mathrm{K}^{+}$channels [41]. Therefore, the predominant role of endocannabinoid receptors is to modulate cell excitability.

\section{1. $C B_{1}$ and $C B_{2}$ are promiscuous GPCRs capable of oligomerisation}

Although the majority of work on $\mathrm{CB}_{1}$ and $\mathrm{CB}_{2}$ receptors has focussed on their coupling to $\mathrm{G \alpha}_{\mathrm{i} / \mathrm{o}}$, both of these endocannabinoid receptors are now understood to be among the GPCRs capable of coupling to numerous $\mathrm{G}$ proteins in a manner often described as promiscuous coupling. For example, $\mathrm{CB}_{1}$ is proposed to heteromerise with the dopamine receptor type 2 long form $\left(D_{2 L}\right)$, the $\mu$-, $\kappa$-, and $\delta$-opioid receptors, the orexin- 1 receptor, the $A_{2 A}$ adenosine receptor $\left(A_{2 A}\right)$ and the $\beta_{2}$ adrenergic receptor $\left(\beta_{2}-A R\right)$ [84-90]. Importantly, $C B$ receptor coupling to alternative pathways appears to be particularly prevalent in the case of oligomer formation [91]. Such alternative pathways can also be unmasked with the blockade of the $\mathrm{G}_{\mathrm{i}}$ pathway with pertussis toxin (PTX), or can be dependent on the $\mathrm{CB}_{1}$ agonist used [91].

The most widely documented incidence of $\mathrm{CB}$ receptor promiscuity is $\mathrm{CB}_{1}$ coupling to $\mathrm{G} \alpha_{\text {s }}$ proteins [91-93], by which adenylyl cyclase is activated and cAMP response element binding (CREB) protein becomes phosphorylated [94]. As activation of GPCRs coupled to $\mathrm{G} \alpha_{\mathrm{i} / \mathrm{o}}-$ such as $\mathrm{CB}_{1}$ and $\mathrm{CB}_{2}$ receptors - results in the inhibition of adenylyl cyclase and a subsequent decrease in cAMP levels, the activation of GPCRs coupled to $G \alpha_{s}$ therefore initiates an almost opposite cellular response to that which is typically associated with $\mathrm{CB}_{1}$ and $\mathrm{CB}_{2}$ receptors. The $\mathrm{G} \alpha_{\mathrm{s}}$ phenotype was first seen upon co-stimulation of primary rat striatal neuronal cultures, and upon $\mathrm{G}_{\mathrm{i} / \mathrm{o}}$ inhibition in $\mathrm{CHO}$ cells expressing human $\mathrm{CB}_{1}\left(\mathrm{CHO}-\mathrm{hCB}_{1}\right)$ [92]. When stimulated with either quinpirole (a $\mathrm{D}_{2}$ receptor agonist) or $\mathrm{HU} 210$ (a $\mathrm{CB}_{1}$ receptor agonist) alone, forskolin-induced cAMP was inhibited in striatal neurons in a typical $\mathrm{Ga}_{\mathrm{i}}$ ${ }_{\mathrm{o}}$-mediated response. However, co-stimulation with both quinpirole and HU210 reversed this inhibitory response, resulting in an augmented cAMP accumulation in a dose-dependent manner, indicating that $\mathrm{CB}_{1}$ $\mathrm{D}_{2}$ oligomers signal through $\mathrm{Ga}_{\mathrm{s}}$ [92]. Meanwhile, this same study demonstrated that stimulation of $\mathrm{CHO}-\mathrm{hCB}_{1}$ cells with $\mathrm{HU} 210$ resulted in a dose-dependent cAMP inhibition, yet blockade of $\mathrm{G}_{\mathrm{i} / \mathrm{o}}$ with PTX resulted in a dose-dependent cAMP accumulation in the absence of either quinpirole co-stimulation or indeed the $\mathrm{D}_{2}$ receptor, thus indicating that the $\mathrm{CB}_{1}$ receptor alone is sufficient to induce a non- $G \alpha_{i / o}$ signalling profile [92]. A more recent study has indicated that combined $\mathrm{D}_{2}$ antagonism with haloperidol and $\mathrm{CB}_{1}$ agonism with ACEA in $\mathrm{CB}_{1}-\mathrm{D}_{2 \mathrm{~L}}$ heteromers in $\mathrm{STHdh} \mathrm{Q}^{\mathrm{Q} / \mathrm{Q} 7}$ not only enhances $\mathrm{CB}_{1}$ coupling to $\mathrm{G} \alpha_{s}$, but haloperidol in fact behaves as an allosteric modulator of $\mathrm{CB}_{1}$ coupling the $\mathrm{Ga}_{\mathrm{s}}$ [95]. It has been hypothesised that the physiological relevance of such a functional switch is to provide discrete regulation of neurotransmitter signals [92].

Coupling of the $\mathrm{CB}_{1}$ receptor to $\mathrm{G \alpha}_{\mathrm{q}}[96,97]$ has also been reported, with a physiological role for $\mathrm{Ga}_{\mathrm{q}}$-coupled $\mathrm{CB}_{1}$ having been suggested in the induction of autaptic long term depression (autLTD). In primary hippocampal neuronal cultures, autLTD can be induced with an 
intermittent low-frequency stimulus. However, autLTD was strongly diminished when 2-AG production was blocked with a DAG lipase inhibitor, reversed when neurons were treated with the $\mathrm{CB}_{1}$-selective antagonist SR141716, and absent altogether in primary hippocampal neuronal cultures from $\mathrm{CB}^{-} /^{-}$mice [97]. However, autLTD induction could not be prevented with the treatment of pertussis toxin and thus blockade of $\mathrm{G}_{\mathrm{i} / \mathrm{o}}$ [97]. Indeed, the induction of LTD is dependent on the presynaptic accumulation of PLC and filled $\mathrm{Ca}^{2+}$ stores, consistent with $\mathrm{Ga}_{\mathrm{q}}$ coupling. While autLTD remains poorly understood in relation to other forms of synaptic plasticity and depression, this study also indicated that autLTD was dependent on either ionotropic or Group I metabotropic glutamate receptors. The authors thus concluded that the activation of the $\mathrm{CB}_{1}$ receptor and subsequent coupling to $\mathrm{G \alpha}_{\mathrm{q}}$ confers the release of presynaptic glutamate [97].

Lastly, $\mathrm{CB}_{1}$ coupling to $\mathrm{Ga}_{\mathrm{z}}$ has been implicated in cross-tolerance with the $\mu$-opioid receptor arising from receptor desensitisation by regulation of adenylyl cyclase activity and the gating of certain $\mathrm{K}^{+}$ channels [98]. The $\mathrm{CB}_{1}$ receptor co-precipitated with histidine triad nucleotide binding protein 1 (HINT1) - a signalling motif associated with $\mathrm{Ga}_{\mathrm{z}}$ coupling in the $\mu$-opioid receptor - in the periaqueductal grey matter of mice. $\mathrm{CB}_{1}$ receptor association with HINT1 was further increased following WIN55212, although in mice where $\mathrm{Ga}_{\mathrm{z}}$ protein levels had been decreased with oligodeoxynucleotides directed against $\mathrm{Ga}_{\mathrm{z}}$, no WIN55212 desensitisation was seen [98]. Increased association with HINT1 was not seen following THC administration, indicating that only exposure to certain cannabinoids results in increased coupling to $\mathrm{Ga}_{\mathrm{z}}$ and thus desensitisation [98]. The authors of this study therefore hypothesised that certain cannabinoids may determine a $G$ protein bias upon ligand binding, a phenomenon which could therefore be of therapeutic use, as the choice of ligand could dictate $G$ protein coupling and thus functional outcome.

$\mathrm{CB}$ receptor $\mathrm{G}$ protein promiscuity has also been observed in $\mathrm{CB}_{2}$ receptor coupling to $\mathrm{G} \alpha_{\mathrm{s}}[99,100]$, which has recently been implicated in wound healing in the cornea [101]. However, there is a surprising paucity of data on this matter relative to that surrounding $\mathrm{G}$ protein promiscuity at $\mathrm{CB}_{1}$, indicating the need for further research in this field.

Both the cannabinoid agonist used and the expression level of $\mathrm{G} \alpha_{i}$ have been recently shown as crucial to the switch in $\mathrm{G}$ protein coupling in cannabinoid receptors [91]. Indeed, the functional switch from $\mathrm{G \alpha}_{\mathrm{i}}$ to $G \alpha_{s}$ coupling was reversible by both pharmacological knockdown with an irreversible $\mathrm{CB}_{1}$ antagonist (AM6544) and by increasing $\mathrm{G \alpha}_{\mathrm{i}}$ expression levels [91]. Collectively, this has led to the hypothesis that alternative signalling pathways are initiated upon $\mathrm{G \alpha}_{\mathrm{i}}$ exhaustion, due either to $\mathrm{G \alpha}_{\mathrm{i}}$ inactivation or sequestration by another receptor such as the $D_{2}$ dopamine receptor $[91,95]$. The dependency of $G$ protein coupling on the choice of ligand indicates that, akin to many GPCRs, pathway bias in $\mathrm{CB}$ receptors may be therapeutically useful when targeting specific, disease-related pathways. The phenomenon of $\mathrm{CB}$ receptor promiscuity raises the possibility of the activation of different pathways in different physiological contexts, and highlights a far greater level of complexity in endocannabinoid signalling than was originally realised when $\mathrm{CB}_{1}$ and $\mathrm{CB}_{2}$ were first cloned in the early 1990s.

\subsection{GPR55 - a recently deorphanised, third cannabinoid receptor}

GPR55 has functions in both the periphery and the CNS. In the periphery, GPR55 is expressed in the adrenal glands, endothelial cells and the gastrointestinal (GI) tract $[36,76,102]$. Surprisingly, evidence has been found for both pro- and anti-inflammatory effects of GPR55 in the periphery. LPI produced by macrophages is increased during inflammatory conditions [103], while LPI and AM251 (an agonist at GPR55) induce a directional migration of human peripheral blood neutrophils [104], and activation of GPR55 increases pro-inflammatory cytokine release from monocytes and natural killer cells [105-107]. On the other hand, GPR55 has also been found to attenuate neuroinflammation and chronic pain in a dinitrobenzenesulfonic acidinduced colitis model $[108,109]$. It is therefore likely that the role of GPR55 is dependent upon physiological context and inflammatory conditions.

In the CNS, GPR55 is found in several regions of the brain, the caudate nucleus, putamen, hippocampus, thalamus, pons, cerebellum, frontal cortex and hypothalamus [36,102]. GPR55 has also been reported to be located on neural stem cells, where it is proposed to have functions in neural stem cell proliferation, neuronal survival, neuronal differentiation [30] and the regulation of growth cone morphology [110]. Of note, recent evidence indicates that GPR55 activation in the hippocampus can boost glutamate release and modulate synaptic plasticity in the CA1 region [111,112].

In contrast to $\mathrm{CB}_{1}$ and $\mathrm{CB}_{2}$ receptors, GPR55 is coupled to $\mathrm{G \alpha}_{12 / 13}$ $[32,36,113]$ and $\mathrm{Ga}_{\mathrm{q}}$ proteins [76,114-117]. Activation of GPR55 therefore results in the activation of RhoA/Rho-associated protein protein kinase (ROCK), protein kinase B (Akt), and PLC pathways thus increasing neuronal excitability $[33,76,118,119]$. Much like the promiscuity of $\mathrm{CB}_{1}$, it is believed that GPR55 G-protein coupling is conferred by the ligand of choice [33]. It is still unclear which $G$ protein is preferred by GPR55; both mice doubly deficient in $G \alpha_{\mathrm{q}}$ and $\mathrm{G} \alpha_{11}$ in

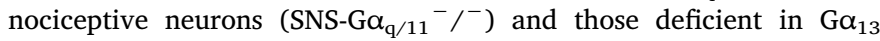
(SNS- $\mathrm{Ga}_{13}{ }^{-} /^{-}$) in nociceptive neurons showed a partial but significant reduction in LPI-induced hypersensitivity, indicating that both $\mathrm{G \alpha}_{\mathrm{q} / 11}$ and $\mathrm{Ga}_{13}$ contribute to LPI-induced hypersensitivity in the same physiological context i.e. nociceptive neurons of the DRG [120]. However, it remains plausible that, akin to $\mathrm{CB}$ promiscuity, $\mathrm{G}$ protein coupling of GPR55 could be dependent on physiological context. Indeed, much early work on GPR55 was carried out in HEK293 cells [32,36,76]; this therefore limits the conclusions which can be drawn about preferential $\mathrm{G}$ protein coupling in vivo.

\section{The endocannabinoid system in Alzheimer's disease}

The endocannabinoid system is one of many neurotransmitter systems affected by Alzheimer's disease. Alterations in $\mathrm{CB}_{1}$ receptor expression and functionality have been described in both $\mathrm{AD}$ animal models [121,122] and the brains of AD patients [123-125]. Interestingly, these alterations vary throughout the progression of $\mathrm{AD}$. In the early stages of disease, both human $\mathrm{AD}$ patients and $\mathrm{AD}$ animal models exhibit an increase in $\mathrm{CB}_{1}$ activity and expression [122,125], perhaps as a neuroprotective response [126]. In contrast, late-stage AD is associated with a reduction of $\mathrm{CB}_{1}$ expression [123] in numerous brain regions including the $\mathrm{CA} 3$ and $\mathrm{CA} 1$ regions of the hippocampus $[127,129]$.

Postmortem brains of $\mathrm{AD}$ patients have indicated that levels of MAGL and FAAH - the breakdown enzymes for 2-AG and anadamide, respectively - are upregulated [131]. Therefore, the early-stage increase in $\mathrm{CB}_{1}$ expression may be in part attributed to a concomitant upregulation of these enzymes and thus overall reduction in endocannabinoid availability. Upregulation of 2-AG via genetic deletion of MAGL in mice surprisingly enhanced LTP, object recognition and spatial memory, with a significantly decreased $\mathrm{CB}_{1}$ receptor binding density [128]. Pan et al. proposed that genetically enhanced 2-AG levels resulted in tonic activation and consequential desensitisation of the $\mathrm{CB}_{1}$ receptor [128]. It is thus plausible that AD-related upregulation of MAGL - initiating a downregulation of 2-AG availability - results in a compensatory upregulation of $\mathrm{CB}_{1}$ receptors and is therefore responsible for the increase in $\mathrm{CB}_{1}$ receptor density seen in the initial stages of $\mathrm{AD}$.

Although $\mathrm{CB}_{2}$ receptor expression levels are relatively low in the healthy brain [83], expression of this receptor is upregulated in amyloid-associated neuroinflammation, seen in both human AD patients and rats inoculated with $\beta$-amyloid [123]. This has been illustrated in mice expressing five familial Alzheimer's disease mutations (5xFAD mouse model) with enhanced green fluorescent protein (EGFP) tagged 
$\mathrm{CB}_{2}$ receptor, which showed enhanced EGFP - and thus $\mathrm{CB}_{2} \mathrm{R}$ - expression at 3 months [129]. This 3 month point represents a point which precedes the onset of cognitive symptoms and deterioration of synaptic transmission in this mouse model, evident at around 6 months. EGFP-CB ${ }_{2} \mathrm{R}$ labelling was detected specifically in areas of intense inflammation and amyloid deposition and was coincident with the appearance of plaques in the cortex, hippocampus, brain stem and thalamus [129]. Furthermore, EGFP expression was restricted to activated microglial cells surrounding neuritic plaques, and was remarkably absent in non-plaque regions, indicating that the upregulation of $\mathrm{CB}_{2} \mathrm{R}$ is directly related to plaque development. This is consistent with observations from postmortem human tissue from patients with neurodegenerative disorders accompanied by inflammation, including $\mathrm{AD}$ [129]. It is not yet clear whether the upregulation of $\mathrm{CB}_{2}$ is a cause or effect of neuritic plaque formation, although it has been suggested that $\mathrm{CB}_{2}$ is induced under neuroinflammatory conditions [129]. Furthermore, given that the first incidence of $\mathrm{CB}_{2} \mathrm{R}$ upregulation in the $5 \mathrm{xFAD}$ mouse model correlates with amyloid deposit at 3 months, Lopez et al. [129] hypothesised that the induction of $\mathrm{CB}_{2}$ receptor expression in the CNS takes place after a period of sustained neuroinflammation, and even postulated that $\mathrm{CB}_{2}$ receptor expression in the CNS could be an early indicator of $\mathrm{AD}$ [129]. Given that $\mathrm{CB}_{2}$ receptor upregulation in the $\mathrm{CNS}$ precedes phenotypic symptoms of $\mathrm{AD}$, this receptor could represent an early target for AD [129].

The endocannabinoid system is thus an attractive target system in $\mathrm{AD}$, particularly in the early stages. Given that many $\mathrm{AD}$ symptoms arise from cholinergic dysfunction, and are paralleled with changes in the endocannabinoid system, there is therefore potential for crosstalk between the endocannabinoid and muscarinic systems. In particular, disease-related changes in endocannabinoid function may offer therapeutic possibilities in AD.

\section{Crosstalk between muscarinic and endocannabinoid receptors - implications for Alzheimer's disease}

Crosstalk has been described between both the nAChRs and mAChRs with the endocannabinoid system. Although $\alpha 7$ nAChR agonism with PNU282987 has been shown to be unaffected by both $\mathrm{CB}_{1}$ antagonism with rimonabant and $\mathrm{CB}_{2}$ antagonism with SR144528 [130], the $\alpha 5$ and $\alpha 6$ nAChRs have been recently implicated in THC dependency and withdrawal [131]. Therefore, although nAChR crosstalk with the endocannabinoid system may not be directly related to $\mathrm{AD}$, this highlights the potential for the cannabinoid system to influence global cholinergic signalling and is thus a crucial consideration in the use of cannabinoids to target the cholinergic system in AD.

The crosstalk between $\mathrm{CB}_{1}$ and muscarinic receptors in $\mathrm{AD}$ has been recently investigated using the triple transgenic mouse model of AD the 3xTg-AD model - in which mice are homozygous for the PSEN1 (presenilin-1) mutation, APP (amyloid precursor protein) Swe transgene, and tauP301L transgene. 3xTg-AD mice exhibit impaired synaptic plasticity, which is thought to arise from the dysregulation of hippocampal presynaptic muscarinic neurotransmission, thus inhibiting memory creation and maintenance [132]. In these mice, intraneuronal $\mathrm{A} \beta$ appears at 2-4 months alongside impaired mAChR-mediated signalling [133], with cognitive impairment being accompanied by elevated $\mathrm{CB}_{1}$ expression at around 7 months $[126,134]$. While cognitive impairment becomes more evident in middle-aged (13-15 months) mice, a simultaneous decrease in choline acetyltransferase and $\mathrm{CB}_{1}$ expression is seen $[126,134]$. In late life $(18-20$ months), these mice exhibit hippocampal and cortical cholinergic neuritic dystrophy, paralleled with the progression of amyloid- $\alpha$ plaque formation [132]. These changes in both $\mathrm{mAChR}$ and $\mathrm{CB}_{1}$ expression and function are parallel to those seen in human $\mathrm{AD}$ as discussed above. Indeed, a positive and statistically significant correlation was found between $\mathrm{CB}_{1}$ receptor density in the basolateral amygdala and acquisition latencies in $3 \times \mathrm{Tg}$ - $\mathrm{AD}$ mice, indicating that changes in $\mathrm{CB}_{1}$ density may contribute to deficits in acquisition [132]. In the 3xTg-AD mouse model, therefore, $\mathrm{CB}_{1}$ expression may influence cognitive function.

The elevated $\mathrm{CB}_{1}$ expression observed in 7-month-old 3xTg-AD mice may represent a therapeutic window. By stimulating the $\mathrm{CB}_{1}$ receptor with the synthetic agonist WIN55212, disease-associated acquisition latencies were reversed at this time point in $3 \mathrm{xTg}-\mathrm{AD}$ mice to levels comparable with non-Tg control mice [132]. Furthermore, WIN55212 reversed disease-associated impairments in functional coupling of $\mathrm{M}_{2}$ / $\mathrm{M}_{4}$ mAChRs to $\mathrm{G}_{\mathrm{i} / \mathrm{o}}$ proteins in the basolateral amygdala, lateral amygdala and hippocampal CA1 region [132]. Therefore, by both directly activating the $\mathrm{CB}_{1}$ receptor through agonist administration, Llorento-Ovejero et al. [132] reversed both cognitive and functional cholinergic deficits in 3xTg-AD mice. In the 5xFAD model, mice overexpress mutant human APP(695), while also expressing the Swedish, Floridian and London Familial AD mutations, in addition to two FAD mutations M146L and L286V, both of which become overexpressed in the brain due to their regulation by the mouse Thy 1 promoter. In contrast to the 3xTg-AD model, blockade of $\mathrm{CB}_{1}$ with SR141716 - a $\mathrm{CB}_{1}$-specific antagonist - exacerbated neuroinflammation in the 5xFAD mouse model [135]. Despite exacerbating neuroinflammation, antagonist treatment of the $\mathrm{CB}_{1}$ receptor neither attenuated nor exacerbated spatial memory in 5xFAD mice [135]. Meanwhile, the genetic deletion of $\mathrm{CB}_{1}$ has been shown to create an imbalance of excitatory/inhibitory neurotransmission in the hippocampus, drastically accelerating memory impairment and reducing survival in APP/PS1 transgenic mice. The APP/PS1 mouse model is a double transgenic mouse model, expressing a chimeric mouse/human amyloid precursor protein, and a mutant human presenilin 1(PS1-dE9), and represents a model of familial $\mathrm{AD}$ with cognitive impairments, $\mathrm{A} \beta$ plaque deposition and synaptic abnormalities from 6 months of age [138]. The effects of activating, blocking, or deleting the $\mathrm{CB}_{1}$ receptor in mouse models of $\mathrm{AD}$ therefore highlight the importance of $\mathrm{CB}_{1}$ in the modulation of AD-like symptoms, particularly those attributed to cholinergic dysfunction. Importantly, activation of the $\mathrm{CB}_{1}$ receptor in vulnerable limbic areas via a $\mathrm{CB}$ receptor agonist is capable of reversing symptoms of cholinergic deficit and reversing functional mAChR impairments, while blockade or genetic deletion of the $\mathrm{CB}_{1}$ receptor can exacerbate disease. Collectively, this indicates that the early upregulation of $\mathrm{CB}_{1}$ expression in $\mathrm{AD}$ may serve a pivotal, and druggable, role in an attempt to protect cholinergic function via CB1-mediated pathways.

While direct activation of $\mathrm{CB}_{1}$ has shown promising effects, enhancing synaptic endocannabinoid availability through blockade of MAGL and FAAH has yielded mixed results. The pharmacological inhibition of MAGL - thus increasing synaptic availability of 2-AG - with JZL-184 showed the same reversal of acquisition latencies seen in 7month 3xTg-AD mice as $\mathrm{CB}_{1}$ activation with WIN55212 [132], and improvements in spatial learning and memory with simultaneous repressed $\beta$-amyloid accumulation in 5xFAD mice [136]. However, unlike agonist treatment, JZL-184 had no improvement on functional $\mathrm{M}_{2} / \mathrm{M}_{4}$ mAChR coupling in 3xTg-AD mice [132]. Meanwhile, pharmacological inhibition of FAAH had little effect on cognitive impairment, plaque deposition or inflammatory markers in 5xFAD mice [135], indicating that the pharmacological enhancement of anandamide levels - in contrast to 2-AG enhancement - does little to improve symptoms of AD in this particular mouse model. On the other hand, FAAH-null 5xFAD mice showed a behavioural improvement in spatial memory tasks and diminished levels of both soluble amyloid and neuritic plaque density [135], indicating that perhaps a lifelong upregulation of anandamide availability is protective against the onset of AD-like symptoms in $5 x F A D$ mice. Surprisingly, a paradoxical elevation of pro-inflammatory cytokines levels was also seen in these mice, and the attenuation of memory impairment was not reversed by administration of SR141716 a $\mathrm{CB}_{1}$ antagonist - indicating that genetically elevated anandamide levels do not mediate improvements in spatial memory via $\mathrm{CB}_{1}$ [135]. Given that anandamide also activates GPR55 and $\mathrm{CB}_{2}$, it is possible that genetic deletion of FAAH leads to anandamide acting not only on $\mathrm{CB}_{1}$, 
but instead on the endocannabinoid system as a whole, to improve cognitive function and attenuate the onset of markers of $\mathrm{AD}$. Indeed, as discussed above, the activation of GPR55 leads to the release of glutamate and thus supports LTP formation [111,112]. Furthermore, anandamide has been shown to bind to $\mathrm{M}_{1}$ and $\mathrm{M}_{4} \mathrm{mAChRs}$, where it is thought to bind to allosteric sites $[137,138]$. It is therefore possible that the $\mathrm{CB}_{1}$-independent properties of genetic $\mathrm{FAAH}$ ablation could, in part, be explained by activation of GPR55, $\mathrm{CB}_{2}$ or even binding to non-CB receptors such as the mAChRs.

As discussed above, upregulated $\mathrm{CB}_{2}$ receptor expression in the CNS has been recently implicated in the development of neuroinflammation, and as such could be a target for the treatment of $\mathrm{AD}$. Indeed, genetic deletion of $\mathrm{CB}_{2}$ in $5 \mathrm{xFAD}$ mice $\left(\mathrm{CB}_{2} \mathrm{R}^{-/-} / 5 \mathrm{xFAD}\right)$ showed a small but significant decrease in hippocampal neuritic plaque density [129]. However, these mice did not show any changes in A $31-42$ levels or reduced microgliosis in comparison to their wildtype littermates [129]. Meanwhile, deletion of $\mathrm{CB}_{2}$ in APP/PS1 mice resulted in an improvement of cognitive and learning deficits with a concomitant reduction in neuronal loss, decreased plaque levels and increased expression of $\mathrm{A} \beta$ degrading enzymes [139]. In contrast, however, the pharmacological activation of the $\mathrm{CB}_{2}$ receptor via the $\mathrm{CB}_{2}$-selective agonist JWH-133 may also be beneficial in neurodegeneration. In an okadaic acid rat model of $\mathrm{AD}$, neurodegeneration, neuroinflammation, $\mathrm{A} \beta$ accumulation and impairment of cognitive function were all prevented following daily administration of JWH-133 over a two-week period [140]. Reductions in pathological hallmarks of disease were accompanied by a reversal of spatial memory impairment and anxiety to control levels [140]. Therefore, the precise role of $\mathrm{CB}_{2}$ in neurodegenerative disease remains unclear, although these data collectively indicate that targeting the $\mathrm{CB}_{2}$ receptor could prevent or reverse the formation of neuritic plaques and, importantly, reverse memory impairments in $\mathrm{AD}$.

\section{Cannabinoids modulate the M1 mAChR in pilocarpine-induced seizure}

In addition to its role in learning and memory, the $\mathrm{M}_{1} \mathrm{mAChR}$ has long been implicated in the mediation of seizure onset. While genetic disruption of $\mathrm{M}_{1}$ ablates seizure activity in mice [141], both inhibition of AChE by organophosphorous (OP) compounds [142,143] and treatment with pilocarpine induce seizures in rodents [144]. The latter shows a phenotype similar to human temporal lobe epilepsy, and is thus a widely used model of this disease state [144]. These effects are longlasting, with pilocarpine-treated animals developing spontaneous seizures a few weeks after compound administration. Consistent with the notion that the spontaneous seizures in this model is driven by mAChRs is the fact that pre-treatment with muscarinic antagonists prior to pilocarpine treatment can block the development of spontaneous seizures. However, muscarinic antagonist administration after pilocarpine treatment does not terminate seizure activity. Therefore, mAChRs are required for the development, but not necessarily the maintenance of pilocarpine-induced spontaneous seizures [144].

The effectiveness of directly targeting $\mathrm{CB}_{1}$ in seizure states can be illustrated by both $\mathrm{CB}_{1}$ knockout mouse models and $\mathrm{CB}_{1}$ antagonist administration, both of which increase pilocarpine seizure sensitivity in the pilocarpine-induced seizure model [144]. However, this is not restricted to this particular seizure model, as $\mathrm{CB}_{1}$ ablation and antagonist treatment both produce proconvulsive phenotypes in electroshock, spontaneous and kainic acid seizure models of epilepsy [145-148]. On the other hand, both endocannabinoids and $\mathrm{CB}_{1}$ receptor agonist administration can attenuate seizures in all of these models. Collectively, this is indicative that constitutive $\mathrm{CB}_{1}$ activity via endocannabinoids modulates not only mAChR-driven seizure activity, but also the onset of seizures through other neurotransmitter systems, which is reflective of the fact that the endocannabinoid system is indeed a modulatory system for a breadth of neurotransmitters. A protective role for $\mathrm{CB}_{1}$ has been described in the OP-induced seizure model, whereby $\mathrm{CB}_{1}$ antagonism with AM251 significantly increased mortality in mice [149]. Given that OP-induced seizures are mediated by inhibition of AChE - and thus an augmentation of synaptic acetylcholine - this therefore indicates that presynaptic $\mathrm{CB}_{1}$ receptors play a crucial role in the attenuation of presynaptic acetylcholine release. However, the agonism of $\mathrm{CB}_{1}$ as an approach to the treatment of seizures must be approached with caution, as a maximal dentate activation model of limbic seizures in anaesthetised rats indicated that direct $\mathrm{CB}_{1}$ agonism with WIN55212 resulted in impairments of LTP in addition to seizure attenuation [150]. The same study found that FAAH inhibition with URB597 inhibited seizure in a $\mathrm{CB}_{1}$-dependent manner, while avoiding the deleterious effects seen with WIN55212 [150]. Therefore, while targeting $\mathrm{CB}_{1}$ in seizure models shows therapeutic promise, it may also result in adverse effects. Meanwhile, enhancing endocannabinoid tone appears to result in the same anticonvulsant improvements while avoiding deleterious effects of $\mathrm{CB}_{1}$ agonism. Of great importance, however, is that these studies highlight the involvement and protective nature of $\mathrm{CB}_{1}$ in the modulation of seizures driven by $\mathrm{mAChR}$ overstimulation, and the therapeutic potential for targeting the endocannabinoid system in disorders of cholinergic dysfunction.

Given that the World Health Organisation states that epilepsy continues to affect some 50 million individuals worldwide, the attenuation of seizures via both phyto- and synthetic cannabinoids highlights the enormous potential for further defining the endocannabinoid system as a target for seizures. Anecdotal reports arising from the recent growth of public interest in the use of cannabinoids particularly emphasise the effectiveness of CBD over THC. Indeed, recent placebo-controlled trials have shown that the daily addition of $20 \mathrm{mg}$ per $\mathrm{kg}$ of bodyweight of CBD to antiepileptic medication in Dravet syndrome resulted in a reduction in convulsive-seizure of at least $50 \%$ in $43 \%$ of participants [151], while reducing the frequency of drop seizures in Lennox-Gastaut syndrome by $41.9 \%$ [152]. The effectiveness and popularity of CBD over may be reflected in the differing pharmacology whereby, as discussed earlier, THC is a partial agonist at $\mathrm{CB}_{1}$ and $\mathrm{CB}_{2}$, while $\mathrm{CBD}$ is a NAM at $\mathrm{CB}_{1}$, a partial agonist at $\mathrm{CB}_{2}$ and an inhibitor of anandamide uptake. Adding yet further complexity to the role of cannabinoids in seizure modulation, THC may also be a competitive inhibitor of AChE in vitro [153], thus implying that THC could actually enhance synaptic acetylcholine levels, which would be deleterious in ACh-driven seizures. Therefore, the somewhat complex pharmacological properties of CBD - including blockade of anandamide uptake - may combine to attribute anticonvulsant effects, while direct agonism at $\mathrm{CB}_{1}$ - as seen with THC - may be associated with more adverse effects. Therefore, while the phyto- and synthetic cannabinoids show great promise in the treatment and prevention of seizures, more research is required to elucidate the precise role of the endocannabinoid system, particularly with regards to its role in crosstalk with the muscarinic receptors in disease states, prior to the exploitation of cannabinoids for therapeutic benefit.

\section{Concluding remarks}

The endocannabinoid system is a relatively new research field, the true therapeutic potential of which has not yet been fully elucidated. While many efforts in AD research strive to directly target the mAChRs through either orthosteric or allosteric compounds, emerging evidence indicates that, as modulatory receptors, endocannabinoid receptor crosstalk with mAChRs may serve as a way to indirectly fine tune cholinergic dysregulation. This may be of particular importance during discrete disease stages, such as during the upregulation of $\mathrm{CB}_{1}$ in the early stages of Alzheimer's disease. However, targeting the endocannabinoid system is not without its challenges, as $\mathrm{CB}_{1}$ is the most abundantly expressed GPCR in the CNS and the principal regulator of neuronal function with diverse effects on neuronal responses [149]. Therefore, a deeper understanding around the specific roles of these receptors on discrete neuronal populations, and strategies for directly 
targeting cannabinoid receptors in areas of the CNS relevant to disease are required before the endocannabinoid can be fully exploited as a drug target. Meanwhile, public perception around the recreational use of cannabinoids and the harmful nature of prolonged cannabis-based drug abuse has hampered the commitment of the scientific community to test the notion of the endocannabinoid system as a legitimate target in certain disease settings. Collectively, this highlights the continued need for research to be aimed towards deepening our understanding of the endocannabinoid system to optimise drug design for these emerging targets, and their role in disorders of cholinergic dysfunction such as seizure induction and $\mathrm{AD}$.

\section{Acknowledgements}

KJT and ABT are funded by a Wellcome Trust Collaborative Award 201529/Z/16/Z.

\section{References}

[1] World Health Organization, Dementia, http://www.who.int/news-room/factsheets/detail/dementia, (2017).

[2] M. Prince, M. Knapp, M. Guerchet, P. McCrone, M. Prina, A. Comas-Herrera, R. Wittenberg, B. Adelaja, B. Hu, D. King, A. Rehill, D. Salimkumar, Alzheimer's Society, (2014) Dementia UK: Update Second edition. ISBN: 978-1-906647-31-5.

[3] J.L. Cummings, C. Black, The cholinergic hypothesis of neuropsychiatric symptoms in Alzheimer's disease, Am. J. Geriatr. Psychiatry 6 (2) (1998) 64-78.

[4] T. Wyss-Coray, J. Rogers, Inflammation in Alzheimer disease - a brief review on the basic science and clinical literature, Cold Spring Harb. Perspect. Med. 2 (2012) a006346.

[5] H.W. Querfurth, F. LaFerla, Alzheimer's disease, N. Engl. J. Med. 362 (2010) 329-344.

[6] E. Perry, M. Walker, J. Grace, R. Perry, Acetylcholine in mind: a neuro-transmitter correlate of consciousness? Trends Neurosci. 22 (1999) 273-280.

[7] A.V. Terry, J.J. Buccafusco, The cholinergic hypothesis of age and Alzheimer's disease-related cognitive deficits: recent challenges and their implications for novel drug development, J. Pharmacol. Exp. Ther. 306 (3) (2003) 821-827.

[8] J.T. Coyle, D.L. Price, M.R. DeLong, Alzheimer's disease: a disorder of cortical cholinergic innervation, Science 219 (4589) (1983) 1184-1190.

[9] F.M. LaFerla, K.N. Green, S. Oddo, Intracellular amyloid-beta in Alzheimer's disease, Nat. Rev. Neurosci. 8 (7) (2007) 499-509.

[10] R.T. Bartus, R.L. Dean 3rd, B. Beer, A.S. Lippa, The cholinergic hypothesis of geriatric memory dysfunction, Science 217 (1982) 408-414.

[11] B.M. McGleenon, K.B. Dynan, A.P. Passmore, Acetylcholinesterase inhibitors in Alzheimer's disease, Br. J. Clin. Pharmacol. 48 (4) (1999) 471-480.

[12] L.W. Chu, E.S. Ma, K.K. Lam, M.F. Chan, D.H. Lee, Increased alpha 7 nicotinic acetylcholine receptor protein levels in Alzheimer's disease patients, Dement. Geriatr. Cogn. Disord. 19 (2-3) (2005) 106-112.

[13] D. Puzzo, L. Privitera, E. Leznik, M. Fà, A. Staniszewski, A. Palmeri, O. Arancio, Picomolar amyloid-beta positively modulates synaptic plasticity and memory in hippocampus, J. Neurosci. 28 (53) (2008) 14537-14545.

[14] J.P. Cleary, D.M. Walsh, J.J. Hofmeister, G.M. Shankar, M.A. Kuskowski, D.J. Selkoe, K.H. Ashe, Natural oligomers of the amyloid-beta protein specifically disrupt cognitive function, Nat. Neurosci. 8 (1) (2005) 79-84.

[15] H.Y. Wang, A. Stucky, J. Liu, C. Shen, C. Trocme-Thibierge, P. Morain, Dissociating beta-amyloid from alpha 7 nicotinic receptor by a novel therapeutic agent, S 24795, normalizes alpha 7 nicotinic acetylcholine and NMDA receptor function in Alzheimer's disease brain, J. Neurosci. 29 (35) (2009) 10961-10973.

[16] S. Sydserff, E.J. Sutton, D. Song, M.C. Quirk, C. Maciag, C. Li, G. Jonak, D. Gurley, J.C. Gordon, E.P. Christian, J.J. Doherty, T. Hudzik, E. Johnson, L. Mrzljak, T. Piser, G.N. Smagin, Y. Wang, D. Widzowski, J.S. Smith, Selective alpha 7 nicotinic receptor activation by AZD0328 enhances cortical dopamine release and improves learning and attentional processes, Biochem. Pharmacol. 78 (7) (2009) $880-888$.

[17] P. Pichat, O.E. Bergis, J.P. Terranova, A. Urani, C. Duarti, V. Santucci, C. Gueudet, C. Voltz, R. Steinberg, J. Stemmelin, F. Ourny-Donat, P. Avenet, G. Griebel, B. Scatton, SSR1180711, a novel selective alpha7 nicotinic receptor partial agonist: (II) efficacy in experimental models predictive of activity against cognitive symptoms of schizophrenia, Neuropsychopharmacology 32 (1) (2007) 17-34.

[18] J. Wess, Molecular biology of muscarinic acetylcholine receptors, Crit. Rev. Neurobiol. 10 (1996) 69-99.

[19] M.P. Caulfield, N.J.M. Birdsall, International union of pharmacology. XVII. Classification of muscarinic acetylcholine receptors, Pharmacol. Rev. 50 (1998) 279-290.

[20] J. Wess, R.E. Eglen, D. Gautam, Muscarinic acetylcholine receptors: mutant mice provide new insights for drug development, Nat. Rev. Drug Discov. 6 (2007) 721-733.

[21] P.J. Nathan, J. Watson, J. Lund, C.H. Davies, G. Peters, C.M. Dodds, B. Swirski, P. Lawrence, G.D. Bentley, B.V. O'Neill, J. Robertson, S. Watson, G.A. Jones, P. Maruff, R.J. Croft, M. Laruelle, E.T. Bullmore, The potent $\mathrm{M}_{1}$ receptor allosteric agonist GSK1034702 improves episodic memory in humans in the nicotine abstinence model of cognitive dysfunction, Int. J. Neuropsychopharmacol. 16 (4) (2013) 721-731.

[22] R. Rodriguez-Puertas, J. Pascual, T. Vilaro, A. Pazos, Autoradiographic distribution of M1, M2, M3, and M4 muscarinic receptor subtypes in Alzheimer's disease, Synapse 26 (1997) 341-350.

[23] N.C. Bodick, W.W. Offen, A.I. Levey, N.R. Cutler, S.G. Gauthier, A. Satlin, H.E. Shannon, G.D. Tollefson, K. Rasmussen, F.P. Bymaster, D.J. Hurley, W.Z. Potter, S.M. Paul, Effects of xanomeline, a selective muscarinic receptor agonist, on cognitive function and behavioral symptoms in Alzheimer disease, Arch. Neurol. 54 (4) (1997) 465-473.

[24] F.P. Bymaster, P.A. Carter, S.C. Peters, W. Zhang, J.S. Ward, C.H. Mitch, D.O. Calligaro, C.A. Whitesitt, N. DeLapp, H.E. Shannon, K. Rimvall, L. Jeppesen, M.J. Sheardown, A. Fink-Jensen, P. Sauerberg, Xanomeline compared to other muscarinic agents on stimulation of phosphoinositide hydrolysis in vivo and other cholinomimetic effects, Brain Res. 795 (1-2) (1998) 179-190.

[25] A.C. Kruse, H. Jianxin, A.C. Pan, D.H. Arlow, D.M. Rodenbaum, E. Rosemond, H.F. Green, T. Liu, P.S. Chae, R.O. Dror, D.E. Shaw, W.I. Weis, W. Jurgen, B. Kobilka, Structure and dynamics of the M3 muscarinic acetylcholine receptor, Nature 482 (7386) (2012) 552-556.

[26] S.P. Moran, J.W. Dickerson, H.P. Cho, Z. Xiang, J. Maksymetz, D.H. Remke, X. Lv, C.A. Doyle, D.H. Rajan, C.M. Niswender, D.W. Engers, C.W. Lindsley, J.M. Rook, P.J. Conn, $\mathrm{M}_{1}$-positive allosteric modulators lacking agonist activity provide the optimal profile for enhancing cognition, Neuropsychopharmacology 43 (8) (2018) $1763-1771$.

[27] S.J. Bradley, J.-M. Bourgognon, A.J. Butcher, H.E. Sanger, N. Verity, J.A. Moreno, C. Molloy, T. Macedo-Hatch, J.M. Edwards, J. Wee, R. Pawlak, D.J. Read, P.M. Sexton, L.M. Broad, G.R. Mallucci, A. Christopoulos, C.C. Felder, J.R. Steinert, A.B. Tobin, M1 muscarinic acetylcholine receptor allosteric modulators rescue memory loss in prion neurodegeneration, J. Clin. Investig. 127 (2) (2017) 487-499.

[28] B. Liu, C.H. Croy, S.A. Hitchcock, J.R. Allen, Z. Rao, D. Evans, M.G. Bures, D.L. McKinzie, M.L. Watt, G.S. Gregory, M.M. Hansen, P.J. Hoogestraat, J.A. Jamison, F.O. Okha-Mokube, R.E. Stratford, W. Turner, F. Bymaster, C.C. Felder, Design and synthesis of $N$-[6-(substituted aminoethylideneamino)-2hydroxyindan-1-yl]arylamides as selective and potent muscarinic $\mathrm{M}_{1}$ agonists, Bioorg. Med. Chem. Lett. 25 (19) (2015) 4158-4163.

[29] S.J. Bradley, C. Molloy, C. Bundgaard, A.J. Mogg, K.J. Thompson, L. Dwomoh, H.E. Sanger, M.D. Crabtree, S.M. Brooke, P.M. Sexton, C.C. Felder, A. Christopoulos, L.M. Broad, A.B. Tobin, C.J. Langmead, Bitopic binding mode of an $\mathrm{M}_{1}$ muscarinic acetylcholine receptor agonist associated with adverse clinical trial outcomes, Mol. Pharmacol. 93 (2018) 645-656.

[30] J.D. Hill, V. Zuluaga-Ramirez, S. Gajghate, M. Winfield, Y. Peridsky, Activation of GPR55 increases neural stem cell proliferation and promotes early adult hippocampal neurogenesis, Br. J. Pharmacol. 175 (16) (2018) 3407-3421.

[31] J.D. Hill, V. Zuluaga-Ramirez, S. Gajghate, M. Winfield, U. Sriram, S. Rom, Y. Persidsky, Activation of GPR55 induces neuroprotection of hippocampal neurogenesis and immune responses of neural stem cells following chronic, systemic inflammation, Brain Behav. Immun. 76 (2019) 165-181.

[32] S. Oka, K. Nakajima, A. Yamashita, S. Kishimoto, T. Sugiura, Identification of GPR55 as a lysophosphatidylinositol receptor, Biochem. Biophys. Res. Commun. 362 (2007) 928-934.

[33] C.M. Henstridge, N.A. Balenga, R. Schroder, J.K. Kargl, W. Platzer, L. Martini, S. Arthur, J. Penman, J.L. Whistler, E. Kostenis, M. Waldhoer, A.J. Irving, GPR55 ligands promote receptor coupling to multiple signalling pathways, Br. J. Pharmacol. 160 (3) (2010) 604-614.

[34] S. Heynen-Genel, R. Dahl, S. Shi, L. Milan, S. Hariharan, E. Sergienko, M. Hedrick, S. Dad, D. Stonich, Y. Su, M. Vicchiarelli, A. Mangravita-Novo, L.H. Smith, T.D.Y. Chung, H. Sharir, M.G. Caron, L.S. Barak, M.E. Abood, Screening for selective ligands for GPR55 - antagonists, Probe Reports from the NIH Molecular Libraries Program, 2010.

[35] L. Fakhouri, C.D. Cook, M.H. Al-Huniti, L.M. Console-Bram, D.P. Hurst, M.B.S. Spano, D.J. Nasrallah, M.G. Caron, L.S. Barak, P.H. Reggio, M.E. Abood, M.P. Croatt, Design, synthesis and biological evaluation of GPR55 agonists, Bioorg. Med. Chem. 25 (16) (2017) 4355-4367.

[36] E. Ryberg, N. Larsson, S. Sjogren, S. Hjorth, N.O. Hermansson, J. Leonova, T. Elebring, K. Nilsson, T. Drmota, P.J. Greasley, The orphan receptor GPR55 is a novel cannabinoid receptor, Br. J. Pharmacol. 152 (7) (2007) 1092-1101.

[37] L. Console-Bram, S.M. Ciuciu, P. Zhao, R.E. Zipkin, E. Brailoiu, M.E. Abood, Narachidonoyl glycine, another endogenous agonist of GPR55, Biochem. Biophys. Res. Commun. 490 (2017) 1389-1393.

[38] O. Elbegdorj, R.B. Westkaemper, Y. Zhang, A homology modeling study toward the understanding of three-dimensional structure and putative pharmacological profile of the G-protein coupled receptor GPR55, J. Mol. Graph. Model. 39 (2013) 50-60.

[39] F. Petitet, M. Donlan, A. Michel, GPR55 as a new cannabinoid receptor: still a long way to prove it, Chem. Biol. Drug Des. 67 (2006) 252-253.

[40] A. Yamashita, S. Oka, T. Tanikawa, Y. Hayashi, Y. Nemoto-Sasaki, T. Sugiura, The actions and metabolism of lysophosphatidylinositol, an endogenous agonist for GPR55, Prostaglandins Other Lipid Mediat. 107 (2013) 103-116.

[41] S.G. Fagan, V.A. Campbell, The influence of cannabinoids on generic traits of neurodegeneration, Br. J. Pharmacol. 171 (2014) 1347-1360.

[42] C.C. Felder, E.M. Briley, J. Axelrod, J.T. Simpson, K. Mackie, W.A. Devane, Anandamide, an endogenous cannabimimetic eicosanoid, binds to the cloned human cannabinoid receptor and stimulates receptor-mediated signal transduction, Proc. Natl. Acad. Sci. U. S. A. 90 (1993) 7656-7660.

[43] J. Priller, E.M. Briley, J. Mansouri, W.A. Devane, K. Mackie, C.C. Felder, Mead 
ethanolamide, a novel eicosanoid, is an agonist for the central $\left(\mathrm{CB}_{1}\right)$ and peripheral $\left(\mathrm{CB}_{2}\right)$ cannabinoid receptors, Mol. Pharmacol. 48 (1995) 288-292.

[44] G. Mattace Raso, R. Russo, A. Calignano, R. Meli, Palmitoylethanolamide in CNS health and disease, Pharmacol. Res. 86 (2014) 32-41.

[45] S. Petrosino, V. Di Marzo, The pharmacology of palmitoylethanolamide and first data on the therapeutic efficacy of some of its new formulations, Br. J. Pharmacol. 174 (2017) 1349-1365.

[46] L. Gabrielsson, S. Mattsson, C.J. Fowler, Palmitoylethanolamide for the treatment of pain: pharmacokinetics, safety and efficacy, Br. J. Clin. Pharmacol. 82 (2016) 932-942.

[47] O. Lykhmus, K. Uspenska, L. Koval, D. Lytovchenko, L. Voytenko, T. Horid'ko, H. Kosiakova, N. Gula, S. Komisarenko, M. Skok, $N$-Stearoylethanolamine protects the brain and improves memory of mice treated with lipopolysaccharide or immunized with the extracellular domain of $\alpha 7$ nicotinic acetylcholine receptor, Int. Immunopharmacol. 52 (2017) 290-296.

[48] K. Tsuboi, T. Uyama, Y. Okamoto, N. Ueda, Endocannabinoids and related $N$ acylethanolamines: biological activities and metabolism, Inflamm. Regen. 38 (2018) 28.

[49] S.E. Turner, C.M. Williams, L. Iversen, B.J. Whalley, Molecular pharmacology of phytocannabinoids, in: A. Kinghorn, H. Falk, S. Gibbons, J. Kobayashi (Eds.), Phytocannabinoids. Progress in the Chemistry of Organic Natural Products, 103 Springer, Cham, 2017.

[50] M. Elsohly, W. Gul, Constituents of Cannabis sativa, in: R.G. Pertwee (Ed.), Handbook of Cannabis, Oxford University Press, Oxford, 2014, pp. 3-22.

[51] M. Tham, O. Yilmaz, M. Alaverdashvili, M.E.M. Kelly, E.M. Denovan-Wright, R.B. Laprairie, Allosteric and orthosteric pharmacology of cannabidiol and cannabidiol — dimethylheptyl at the type 1 and type 2 cannabinoid receptors, Br. J. Pharmacol. 176 (10) (2019) 1455-1469.

[52] C.C. Felder, K.E. Joyce, E.M. Briley, J. Mansouri, K. Mackie, O. Blond, Y. Lai, A.L. Ma, R.L. Mitchell, Comparison of the pharmacology and signal transduction of the human cannabinoid CB1 and CB2 receptors, Mol. Pharmacol. 48 (1995) 443-450.

[53] V.M. Showalter, D.R. Compton, B.R. Martin, M.E. Abood, Evaluation of binding in a transfected cell line expressing a peripheral cannabinoid receptor $\left(\mathrm{CB}_{2}\right)$ : identification of cannabinoid receptor subtype selective ligands, J. Pharmacol. Exp. Ther. 278 (1996) 989-999.

[54] R.G. Pertwee, The diverse $\mathrm{CB}_{1}$ and $\mathrm{CB}_{2}$ receptor pharmacology of three plant cannabinoids: $\Delta^{9}$-tetrahydrocannabinol, cannabidiol and $\Delta^{9}$-tetrahydrocannabivarin, Br. J. Pharmacol. 153 (2) (2008) 199-215.

[55] J.M. McPartland, M. Duncan, V. Di Marzo, R.G. Pertwee, Are cannabidiol and $\Delta^{9}$ tetrahydrocannabibrevin negative modulators of the endocannabinoid system? A systematic review, Br. J. Pharmacol. 172 (3) (2015) 737-753.

[56] R.B. Laprairie, A.M. Bagher, M.E.M. Kelly, D.J. Dupré, E.M. Denovan-Wright, Type 1 cannabinoid receptor ligands display functional selectivity in a cell culture model of striatal medium spiny projection neurons, J. Biol. Chem. 289 (36) (2014) 24845-24862.

[57] R.B. Laprairie, A.M. Bagher, M.E.M. Kelly, E.M. Denovan-Wright, Cannabidiol is a negative allosteric modulator of the type 1 cannabinoid receptor, Br. J. Pharmacol. 172 (2015) 4790.

[58] T. Bisogno, L. Hanus, L. De Petrocellis, S. Tchilibon, D.E. Ponde, I. Brandi, A.S. Moriello, J.B. Davis, R. Mechoulam, V. Di Marzo, Molecular targets for cannabidiol and its synthetic analogues: effect of vanniloid VR1 receptors and on the cellular uptake and enzymatic hydrolysis of anadamide, Br. J. Pharmacol. 134 (2001) 845-852.

[59] L. De Petrocellis, A. Ligresti, A.S. Moriello, M. Allara, T. Bisogno, S. Petrosino, C.G. Stott, V. Di Marzo, Effects of cannabinoids and cannabinoid-enriched Cannabis extracts on TRP channels and endocannabinoid metabolic enzymes, Br. J. Pharmacol. 163 (2011) 1479.

[60] M. Barann, G. Molderings, M. Brüss, H. Bönisch, B.W. Urban, M. Göthert, Direct inhibition by cannabinoids of human 5-HT3A receptors: probable involvement of an allosteric modulatory site, Br. J. Pharmacol. 137 (2002) 589-596.

[61] B. Shi, R. Yang, X. Wang, H. Liu, L. Zou, X. Hu, J. Wu, A. Zou, L. Liu, Inhibition of $5-\mathrm{HT}_{3}$ receptors-activated currents by cannabinoids in rat trigeminal ganglion neurons, J. Huazhong Univ. Sci. Technol. 32 (2012) 265.

[62] S.E. Jordt, D.M. Bautista, H.H. Chuang, D.D. McKemy, P.M. Zygmunt, E.D. Högestätt, I.D. Meng, D. Julius, Mustard oils and cannabinoids excite sensory nerve fibres through the TRP channel ANKTM1, Nature 427 (6971) (2004) 260-265.

[63] N. Qin, M.P. Neeper, Y. Liu, T.L. Hutchinson, M.L. Lubin, C.M. Flores, TRPV2 is activated by cannabidiol and mediates CGRP release in cultured rat dorsal root ganglion neurons, J. Neurosci. 28 (24) (2008) 6231-6238.

[64] E.B. Russo, A. Burnett, B. Hall, K.K. Parker, Agonistic properties of cannabidiol at 5-HT1a receptors, Neurochem. Res. 30 (2005) 1037-1043.

[65] M. Kathmann, K. Flau, A. Redmer, C. Tränkle, E. Schlicker, Cannabidiol is an allosteric modulator at mu- and delta-opioidreceptors, Naunyn Schmiedeberg's Arch. Pharmacol. 372 (2006) 354-361.

[66] A.C. Campos, F.A. Moreira, F.V. Gomes, E.A. Del Bel, F.S. Guimaraes, Multiple mechanisms involved in the large-spectrum therapeutic potential of cannabidiol in psychiatric disorders, Philos. Trans. R. Soc. B 367 (2012) 3364-3378.

[67] R.G. Pertwee, A.C. Howlett, M.E. Abood, S.P. Alexander, V. Di Marzo, M.R. Elphick, P.J. Greasley, H.S. Hansen, G. Kunos, K. Mackie, R. Mechoulam, R.A. Ross, International Union of Basic and Clinical Pharmacology. LXXIX. Cannabinoid receptors and their ligands: beyond CB and CB, Pharmacol. Rev. 62 (4) (2010) 588-631.

[68] T.E. D'Ambra, K.G. Estep, M.R. Bell, M.A. Eissenstat, K.A. Josef, S.J. Ward, D.A. Haycock, E.R. Baizman, F.M. Casiano, N.C. Beglin, S.M. Chippari, J.D. Grego,
R.K. Kulling, G.T. Daley, Conformationally restrained analogues of pravadoline: nanomolar potent, enantioselective, (aminoalkyl)indole agonists of the cannabinoid receptor, J. Med. Chem. 35 (1) (1992) 124-135.

[69] D. Shire, B. Calandra, M. Rinaldi-Carmona, D. Oustric, B. Pessegue, O. BonninCabanne, G. Le Fur, D. Caput, P. Ferrara, Molecular cloning, expression and function of the murine $\mathrm{CB}_{2}$ peripheral cannabinoid receptor, Biochim. Biophys. Acta 1307 (1996) 132-136.

[70] S. Munro, K.L. Thomas, M. Abu-Shaar, Molecular characterization of a peripheral receptor for cannabinoids, Nature 365 (1993) 61-65.

[71] C.J. Hillard, S. Manna, M.J. Greenberg, R. DiCamelli, R.A. Ross, L.A. Stevenson, V. Murphy, R.G. Pertwee, W.B. Campbell, Synthesis and characterization of potent and selective agonists of the neuronal cannabinoid receptor (CB1), J. Pharmacol. Exp. Ther. 289 (3) (1999) 1427-1433.

[72] M. Rinaldi-Carmona, F. Barth, M. Heaulme, D. Shire, B. Calandra, C. Congy, S. Martinez, J. Maruani, G. Neliat, D. Caput, P. Ferrara, P. Soubrie, J.C. Breliere, G. Le Fur, SR141716A, a potent and selective antagonist of the brain cannabinoid receptor, FEBS Lett. 350 (2-3) (1994) 240-244.

[73] J.W. Huffman, J. Liddle, S. Yu, M.M. Aung, M.E. Abood, J.L. Wiley, B.R. Martin, 3(1',1'-Dimethylbutyl)-1-deoxy- $\Delta^{8}$-THC and related compounds: synthesis of selective ligands for the $\mathrm{CB}_{2}$ receptor, Bioorg. Med. Chem. 7 (12) (1999) 2905-2914.

[74] D. Baker, G. Pryce, J.L. Croxford, P. Brown, R.G. Pertwee, J.W. Huffman, L. Layward, Cannabis controls spasticity and tremor in a multiple sclerosis model, Nature 404 (2000) 84-87.

[75] J.W. Huffman, S. Yu, V. Showalter, M.E. Abood, J.L. Wiley, D.R. Compton, B.R. Martin, D. Bramblett, P.H. Reggio, Synthesis and pharmacology of a very potent cannabinoid lacking a phenolic hydroxyl with high affinity for the CB2 receptor, J. Med. Chem. 39 (20) (1996) 3875-3877.

[76] J.E. Lauckner, J.B. Jensen, H.Y. Chen, H.C. Lu, B. Hille, K. Mackie, GPR55 is a cannabinoid receptor that increases intracellular calcium and inhibits M current, Proc. Natl. Acad. Sci. U. S. A. 105 (7) (2008) 2699-2704.

[77] S. Heynen-Genel, R. Dahl, S. Shi, L. Milan, S. Hariharan, Y. Bravo, E. Sergienko, M. Hedrick, S. Dad, D. Stonich, Y. Su, M. Vicchiarelli, A. Mangravita-Novo, L.H. Smith, T.D.Y. Chung, H. Sharir, L.S. Barak, M.E. Abood, Screening for selective ligands for gpr55 - agonists, Probe Reports from the NIH Molecular Libraries Program, 2010.

[78] L.A. Matsuda, S.J. Lolait, M.J. Brownstein, A.C. Young, T.I. Bonner, Structure of a cannabinoid receptor and functional expression of the cloned cDNA, Nature 346 (1990) 561-564.

[79] A.C. Howlett, Cannabinoid receptor signalling, Handb. Exp. Pharmacol. 168 (2005) 53-79.

[80] G.A. Cabral, G.A. Ferreira, M.J. Jamerson, Endocannabinoids and the immune system in health and disease, in: R.G. Pertwee (Ed.), Endocannabinoids, Handbook of Experimental Pharmacology, 231 2015, pp. 185-212.

[81] A.V. Stempel, A. Stumpf, H.-Y. Zhang, T. Özdoğan, U. Pannasch, A.-K. Theis, D.M. Otte, A. Wojtalla, I. Rácz, A. Ponomarenko, Z.-X. Xi, A. Zimmer, D. Schmitz, Cannabinoid type 2 receptors mediate a cell type-specific plasticity in the hippocampus, Neuron 90 (4) (2016) 795-809.

[82] A.M. Martin-Moreno, B. Brera, C. Spuch, E. Carro, L. García-García, M. Delgado, M.A. Pozo, N.G. Innamorato, A. Cuadrado, M.L. de Ceballos, Prolonged oral cannabinoid administration prevents neuroinflammation, lowers $\beta$-amyloid levels and improves cognitive performance in Tg APP 2576 mice, J. Neuroinflammation 9 (2012) 8

[83] T. Bisogno, S. Oddi, A. Piccoli, D. Fazio, M. Maccarrone, Type-2 cannabinoid receptors in neurodegeneration, Pharmacol. Res. 111 (2016) 721-730.

[84] J. Wager-Miller, R. Westenbroek, K. Mackie, Dimerization of G protein-coupled receptors: $\mathrm{CB} 1$ cannabinoid receptors as an example, Chem. Phys. Lipids 121 (2002) 83-89.

[85] C.S. Kearn, K. Blake-Palmer, E. Daniel, K. Mackie, M. Glass, Concurrent stimulation of cannabinoid CB1 and dopamine D2 receptors enhances heterodimer formation: a mechanism for receptor cross-talk? Mol. Pharmacol. 67 (2005) 1697-1704.

[86] K. Mackie, Cannabinoid receptor homo- and heterodimerization, Life Sci. 77 (2005) 1667-1673.

[87] J. Ellis, J.D. Pediani, M. Canals, S. Milasta, G. Milligan, Orexin-1 receptor-cannabinoid CB1 receptor heterodimerization results in both ligand-dependent and -independent coordinated alterations of receptor localization and function, J. Biol. Chem. 281 (2006) 38812-38824.

[88] C. Rios, I. Gomes, L.A. Devi, $\mu$ opioid and CB1 cannabinoid receptor interactions: reciprocal inhibition of receptor signaling and neuritogenesis, Br. J. Pharmacol. 148 (2006) 387-395.

[89] P. Carriba, O. Ortiz, K. Patkar, Z. Justinova, J. Stroik, A. Themann, C. Müller, A.S. Woods, B.T. Hope, F. Ciruela, V. Casado, E.I. Canela, C. Lluis, S.R. Goldberg, R. Moratalla, R. Franco, S. Ferre, Striatal adenosine A2A and cannabinoid CB1 receptors form functional heteromeric complexes that mediate the motor effects of cannabinoids, Neuropsychopharmacology 32 (2007) 2249-2259.

[90] B.D. Hudson, T.E. Hébert, M.E. Kelly, Physical and functional interaction between CB1 cannabinoid receptors and $\beta 2$-adrenoceptors, Br. J. Pharmacol. 160 (2010) 627-642.

[91] D.B. Finlay, E.E. Cawston, N.L. Grimsey, M.R. Hunter, A. Korde, V.K. Vemuri, A. Makriyannis, M. Glass, Gas signalling of the $\mathrm{CB}_{1}$ receptor and the influence of receptor number, Br. J. Pharmacol. 174 (15) (2017) 2545-2562.

[92] M. Glass, C.C. Felder, Concurrent stimulation of cannabinoid $\mathrm{CB}_{1}$ and Dopmaine $D_{2}$ receptors augments cAMP accumulation in striatal neurons: evidence for a $G_{s}$ linkage to the $\mathrm{CB}_{1}$ receptor, J. Neurosci. 17 (14) (1997) 5327-5333.

[93] D.W. Bonhaus, L.K. Chang, J. Kwan, G.R. Martin, Dual activation and inhibition of adenylyl cyclase by cannabinoid receptor agonists: evidence for agonist-specific 
trafficking of intracellular responses, J. Pharmacol. Exp. Ther. 287 (1998) 884-888.

[94] M.S. Ibsen, M. Connor, M. Glass, Cannabinoid CB1 and CB2 receptor signaling and bias, Cannabis and Cannabinoid Res. 2 (1) (2017) 48-60.

[95] A.M. Bagher, R.B. Laprairie, M.E. Kelly, E.M. Denovan-Wright, Antagonism of dopamine receptor 2 long (D2L) affects cannabinoid receptor 1 (CB1) signaling in a cell culture model of striatal medium spiny projection neurons, Mol. Pharmacol. 89 (2016) 652-666.

[96] J.E. Lauckner, B. Hille, K. Mackie, The cannabinoid agonist WIN55,212-2 increases intracellular calcium via CB1 receptor coupling to Gq/11 G proteins, Proc. Natl. Acad. Sci. U. S. A. 102 (2005) 19144-19149.

[97] R. Kellogg, K. Mackie, A. Straiker, Cannabinoid CB1 receptor-dependent long-term depression in autaptic excitatory neurons, J. Neurophysiol. 102 (2009) 1160-1171.

[98] J. Garzon, E. de la Torre-Madrid, M. Rodriguez-Munoz, M. Rodriguez-Munoz, A. Vicente-Sanchez, P. Sanchez-Blazquez, Gz mediates the long-lasting desensitization of brain CB1 receptors and is essential for cross-tolerance with morphine, Mol. Pain 5 (11) (2009), https://doi.org/10.1186/1744-8069-5-11.

[99] A.C. Howlett, F. Barth, T.I. Bonner, G. Cabral, P. Casellas, W.A. Devane, C.C. Felder, M. Herkenham, K. Mackie, B.R. Martin, R. Mechoulam, R.G. Pertwee, International Union of Pharmacology. XXVII. Classification of cannabinoid receptors, Pharmacol. Rev. 54 (2) (2002) 161-202.

[100] M.H. Rhee, M. Bayewitch, T. Avidor-Reiss, R. Levy, Z. Vogel, Cannabinoid receptor activation differentially regulates the various adenylyl cyclase isozymes, $\mathrm{J}$. Neurochem. 71 (1998) 1525-1534.

[101] N. Murataeva, S. Miller, A. Dhopeshwarkar, E. Leishman, L. Daily, X. Taylor, B. Morton, M. Lashmet, H. Bradshaw, C.J. Hillard, J. Romero, A. Straiker, Cannabinoid $\mathrm{CB} 2 \mathrm{R}$ receptors are upregulated with corneal injury and regulate the course of corneal wound healing, Exp. Eye Res. 182 (2019) 74-84.

[102] M. Sawzdargo, Identification and cloning of three novel human G protein-coupled receptor genes GPR52, psi-GPR53, and GPR55: GPR55 is extensively expressed in human brain, Mol. Brain Res. 64 (1999) 193-198.

[103] R.A. Zoeller, P.D. Wightman, M.S. Anderson, C.R. Raetz, Accumulation of lysophosphatidylinositol in RAW 264.7 macrophage tumor cells stimulated by lipid A precursors, J. Biol. Chem. 262 (1987) 17212-17220.

[104] N.A. Balenga, E. Aflaki, J. Kargl, W. Platzer, R. Schroder, S. Blattermann, E. Kostenis, A.J. Brown, A. Heinemann, M. Waldhoer, GPR55 regulates cannabinoid 2 receptor-mediated responses in human neutrophils, Cell Res. 21 (2011) 452-1469.

[105] P.C. Staton, J.P. Hatcher, D.J. Walker, A.D. Morrison, E.M. Shapland, J.P. Hughes, E. Chong, P.K. Mander, P.J. Green, A. Billinton, M. Fulleylove, H.C. Lancaster, J.C. Smith, L.T. Bailey, A. Wise, A.J. Brown, J.C. Richardson, I.P. Chessell, The putative cannabinoid receptor GPR55 plays a role in mechanical hyperalgesia associated with inflammatory and neuropathic pain, Pain 139 (2008) 225-236.

[106] X.H. Lin, B. Yuece, Y.Y. Li, Y.J. Feng, J.Y. Feng, L.Y. Yu, K. Li, Y.N. Li, M. Storr, A novel CB receptor GPR55 and its ligands are involved in regulation of gut movement in rodents, Neurogastroenterol. Motil. 23 (2011) 862-e342.

[107] V. Chiurchiu, M. Lanuti, M. De Bardi, L. Battistini, M. Maccarrone, The differential characterization of GPR55 receptor in human peripheral blood reveals a distinctive expression in monocytes and NK cells and a proinflammatory role in these innate cells, Int. Immunol. 27 (2015) 153-160.

[108] G. Cantarella, M. Scollo, L. Lempereur, G. Saccani-Jotti, F. Basile, R. Bernardini, Endocannabinoids inhibit release of nerve growth factor by inflammation-activated mast cells, Biochem. Pharmacol. 82 (2011) 380-388.

[109] F. Borrelli, B. Romano, S. Petrosino, E. Pagano, R. Capasso, D. Coppola, G. Battista, P. Orlando, V. Di Marzo, A.A. Izzo, Palmitoylethanolamide, a naturally occurring lipid, is an orally effective intestinal anti-inflammatory agent, Br. J. Pharmacol. 172 (1) (2015) 142-158.

[110] H. Cherif, A. Argaw, B. Cecyre, A. Bouchard, J. Gagnon, P. Javadi, S. Desgent, K. Mackie, J.F. Bouchard, Role of GPR55 during axon growth and target innervation, eNeuro 2 (5) (2015) 0011-0015.

[111] K. Hurst, C. Badgley, T. Ellsworth, S. Bell, L. Friend, B. Prince, J. Welch, Z. Cowan, R. Williamson, C. Lyon, B. Anderson, B. Poole, M. Christensen, M. McNeil, J. Call, J.G. Edwards, A putative lysophosphatidylinositol receptor GPR55 modulates hippocampal synaptic plasticity, Hippocampus 27 (9) (2017) 985-998.

[112] S. Sylantyev, T.P. Jensen, R.A. Ross, D.A. Rusakov, Cannabinoid- and lysophosphatidylinositol-sensitive receptor GPR55 boosts neurotransmitter release at central synapses, Proc. Natl. Acad. Sci. U. S. A. 110 (2013) 5193-5198.

[113] C.M. Henstridge, N.A. Balenga, L.A. Ford, R.A. Ross, M. Waldhoer, A.J. Irving, The GPR55 ligand L-alpha-lysophosphatidylinositol promotes RhoA-dependent $\mathrm{Ca}^{2+}$ signaling and NFAT activation, FASEB J. 23 (1) (2009) 183-193.

[114] R.A. Ross, The enigmatic pharmacology of GPR55, Trends Pharmacol. Sci. 30 (3) (2009) 156-163.

[115] T. Nevalainen, A.J. Irving, GPR55, a lysophosphatidylinositol receptor with cannabinoid sensitivity? Curr. Top. Med. Chem. 10 (2010) 799-813.

[116] H. Sharir, M.E. Abood, Pharmacological characterization of GPR55, a putative cannabinoid receptor, Pharmacol. Ther. 126 (2010) 301-313.

[117] Y. Obara, S. Ueno, Y. Yanagihata, N. Nakahata, Lysophosphatidylinositol causes neurite retraction via GPR55, G13 and RhoA in PC12 cells, PLoS One 6 (8) (2011) e24284.

[118] S. Oka, S. Kimura, T. Toshida, R. Ota, A. Yamashita, T. Sugiura, Lysophosphatidylinositol induces rapid phosphorylation of p38 mitogen-activated protein kinase and activating transcription factor 2 in HEK293 cells expressing GPR55 and IM-9 lymphoblastoid cells, J. Biochem. 147 (5) (2010) 671-678.

[119] R.A. Ross, L- $\alpha$-Lysophosphatidylinositol meets GPR55: a deadly relationship, Trends Pharmacol. Sci. 32 (5) (2011) 265-269.
[120] V. Gangadharan, D. Selvaraj, M. Kurejova, C. Njoo, S. Gritsch, D. Skoricova, H. Horstmann, S. Offermanns, A.J. Brown, T. Kuner, A. Tappe-Theodor, R. Kuner, A novel biological role for the phospholipid lysophosphatidylinositol in nociceptive sensitization via activation of diverse G-protein signalling pathways in sensory nerves in vivo, Pain 154 (2013) 2801-2812.

[121] S. Kalifa, E.K. Polston, J.S. Allard, K.F. Manaye, Distribution patterns of cannabinoid CB1 cannabinoid receptors in the hippocampus of APPswe/PS1 $\triangle \mathrm{E} 9$ double transgenic mice, Brain Res. 1376 (2011) 94-100.

[122] E. Aso, E. Palomer, S. Juvés, R. Maldonado, F.J. Muñoz, I. Ferrer, CB1 agonist ACEA protects neurons and reduces the cognitive impairment of AßPP/PS1 mice, J. Alzheimers Dis. 30 (2012) 439-459.

[123] B.G. Ramirez, C. Blazquez, T. Gomez del Pulgar, M. Guzman, M.L. de Ceballos, Prevention of Alzheimer's disease pathology by cannabinoids: neuroprotection mediated by blockade of microglial activation, J. Neurosci. 25 (2005) 1904-1913.

[124] M. Solas, P.T. Francis, R. Franco, M.J. Ramírez, CB2 receptor and amyloid pathology in frontal cortex of Alzheimer's disease patients, Neurobiol. Aging 34 (2013) 805-808.

[125] I. Manuel, E. Gonzalez de San Roman, M.T. Giralt, I. Ferrer, R. Rodriguez-Puertas, Type-1 cannabinoid receptor activity during Alzheimer's disease progression, J. Alzheimers Dis. 42 (2014) 761-766.

[126] I. Manuel, L. Lombardero, F.M. LaFerla, L. Gimenez-Llort, R. Rodriguez-Peurtas, Activity of muscarinic, galanin and cannabinoid receptors in the prodromal and advanced stages of the triple transgenic mice model of Alzheimer's disease, Neuroscience 329 (2016) 284-293.

[127] T.M. Westlake, A.C. Howlett, T.I. Bonner, L.A. Matsuda, M. Herkenham, Cannabinoid receptor binding and messenger RNA expression in human brain: an in vitro receptor autoradiography and in situ hybridization histochemistry study of normal aged and Alzheimer's brains, Neuroscience 63 (1994) 637-652.

[128] B. Pan, W. Wang, P. Zhong, J.L. Blankman, B.F. Cravatt, Q.S. Liu, Alterations of endocannabinoid signalling, synaptic plasticity, learning, and memory in monoacylglycerol lipase knock-out mice, J. Neurosci. 31 (38) (2011) 13420-13430.

[129] A. Lopez, N. Aparicio, M.R. Pazos, M.T. Grande, M.A. Barreda-Manso, I. BenitoCuesta, C. Vazquez, M. Amores, G. Ruiz-Perez, E. Garcia-Garcia, M. Beatka, R.M. Tolon, B.N. Dittel, C.J. Hillard, J. Romero, Cannabinoid CB2 receptors in the mouse brain: relevance for Alzheimer's disease, J. Neuroinflammation 15 (2018) 158.

[130] G. Donvito, D. Bagdas, W. Tomas, E. Rahimpour, A. Jackson, J.A. Meade, S. Al Sharari, A.R. Kulkarni, F.I. Carroll, A.H. Lichtman, R.L. Papke, G.A. Thakur, M.I. Damaj, The interaction between alpha 7 nicotinic acetylcholine receptor and nuclear peroxisome proliferator-activated receptor- $\alpha$ represents a new antinociceptive signaling pathway in mice, Exp. Neurol. 295 (2017) 194-201.

[131] G. Donvito, P.P. Muldoon, K.J. Jackson, U. Ahmad, N.T. Zaveri, J.M. McIntosh, X. Chen, A.H. Lichtman, M.I. Damaj, Neuronal nicotinic acetylcholine receptors mediate $\Delta^{9}$-THC dependence: mouse and human studies, Addict. Biol. 25 (1) (2020) e12691.

[132] A. Llorento-Ovejero, I. Manuel, L. Lombardero, M.T. Giralt, C. Ledent, L. GimenezLlort, R. Rodriguez-Puertas, Endocannabinoid and muscarinic signaling crosstalk in the 3xTg-AD mouse model of Alzheimer's disease, J. Alzheimers Dis. 64 (2018) $117-136$.

[133] L.M. Billings, S. Oddo, K.N. Green, J.L. McGaugh, F.M. LaFerla, Intraneuronal Abeta causes the onset of early Alzheimer's disease-related cognitive deficits in transgenic mice, Neuron 45 (2005) 675-688.

[134] G. Bedse, A. Romano, S. Cianci, A.M. Lavecchia, P. Lorenzo, M.R. Elphick, F.M. Laferla, G. Vendemiale, C. Grillo, F. Altieri, T. Cassano, S. Gaetani, Altered expression of the CB1 cannabinoid receptor in the triple transgenic mouse model of Alzheimer's disease, J. Alzheimers Dis. 40 (3) (2014) 701-712.

[135] C. Vazquez, R.M. Tolon, M.T. Grande, M. Caraza, M. Moreno, E.C. Koester B. Villaescusa, L. Ruiz-Valdepenas, F.J. Fernandez-Sanchez, B.F. Cravatt, C.J. Hillard, J. Romero, Endocannabinoid regulation of amyloid-induced neuroinflammation, Neurobiol. Aging 36 (11) (2015) 3008-3019.

[136] R. Chen, J. Zhang, Y. Wu, D. Wang, G. Feng, Y.-P. Tang, Z. Teng, C. Chen, Monoacylglycerol lipase is a therapeutic target for Alzheimer's disease, Cell Rep. 2 (5) (2012) 1329-1339.

[137] A. Christopoulos, K. Wilson, Interaction of anadamide with the $\mathrm{M}_{1}$ and $\mathrm{M}_{4}$ muscarinic acetylcholine receptors, Brain Res. 915 (2001) 70-78.

[138] A.A. Lanzafame, E. Guida, A. Christopoulos, Effects of anadamide on the binding and signalling properties of $\mathrm{M}_{1}$ muscarinic acetylcholine receptors, Biochem. Pharmacol. 68 (2004) 2207-2219.

[139] A.C. Schmöle, R. Lundt, G. Toprowski, J.N. Hansen, E. Beins, A. Halle, A. Zimmer, Cannabinoid receptor 2-deficiency Ameleriotes disease symptoms in a mouse model with Alzheimer's disease-like pathology, J. Alzheimers Dis. 64 (2) (2018) 379-392.

[140] M. Cakir, S. Tekin, Z. Doganyigit, Y. Erden, M. Soyturk, Y. Cigremis, S. Sandal, Cannabinoid type 2 receptor agonist JWH-133, attenuates okadaic acid induced spatial memory impairment and neurodegeneration in rats, Life Sci. 217 (2019) 25-33.

[141] S.E. Hamilton, M.D. Loose, M. Qi, A.I. Levey, B. Hille, G.S. McKnight, R.L. Idzerda, N.M. Nathanson, Disruption of the $\mathrm{m} 1$ receptor gene ablates muscarinic receptordependent M current regulation and seizure activity in mice, Proc. Natl. Acad. Sci. U. S. A. 94 (1997) 13311-13316.

[142] D. Grob, A.M. Harvey, The effects and treatment of nerve gas poisoning, Am. J. Med. 14 (1953) 52-63.

[143] S.L. Miller, V. Aroniadou-Anderjaska, V.I. Pidoplichko, T.H. Figueiredo, J.P. Apland, J.K. Krishnan, M.F. Braga, The M1 muscarinic receptor antagonist VU0255035 delays the development of status epilepticus after organophosphate exposure and prevents hyperexcitability in the basolateral amygdala, J. 
Pharmacol. Exp. Ther. 360 (2017) 23-32.

[144] R.L. Kow, K. Jiang, A.V. Naydenov, J.H. Le, N. Stella, N.M. Nathanson, Modulation of pilocarpine-induced seizures by cannabinoid receptor 1, PLoS One 9 (4) (2014) e95922.

[145] M.J. Wallace, J.L. Wiley, B.R. Martin, R.J. DeLorenzo, Assessment of the role of CB1 receptors in cannabinoid anticonvulsant effects, Eur. J. Pharmacol. 428 (2001) 51-57.

[146] M.J. Wallace, R.E. Blair, K.W. Falenski, B.R. Martin, R.J. DeLorenzo, The endogenous cannabinoid system regulates seizure frequency and duration in a model of temporal lobe epilepsy, J. Pharmacol. Exp. Ther. 307 (2003) 129-137.

[147] G. Marsicano, S. Goodenough, K. Monory, H. Hermann, M. Eder, A. Cannich, S.C. Azad, M.G. Cascio, S.O. Gutierrez, M. van der Stelt, M.L. Lopez-Rodriguez, E. Casanova, G. Schutz, W. Zieglgansberger, V. Di Marzo, C. Behl, B. Lutz, CB1 cannabinoid receptors and on-demand defense against excitotoxicity, Science 302 (2003) 84-88.

[148] M.E. Hofmann, C.J. Frazier, Marijuana, endocannabinoids, and epilepsy: potential and challenges for improved therapeutic intervention, Exp. Neurol. 244 (2013) 43-50.

[149] K.M. Hoffman, M.R. Eisen, J.K. Chandler, M.R. Nelson, E.A. Johnson,
P.M. McNutt, Retrograde activation of CB1R by muscarinic receptors protects against central organophosphorus toxicity, Neuropharmacology 155 (2019) 113-120.

[150] R. Colangeli, M. Pierucci, A. Benigno, G. Campiani, S. Butini, G. Di Giovanni, The FAAH inhibitor URB597 suppresses hippocampal maximal dentate afterdischarges and restores seizure-induced impairment of short and long-term synaptic plasticity, Sci. Rep. 7 (1) (2017) 11152.

[151] O. Devinsky, J.H. Cross, L. Laux, E. Marsh, I. Miller, R. Nabbout, I.E. Scheffer, E.A. Thiele, S. Wright, Cannabidiol in Dravet Syndrome Study Group, Trial of cannabidiol for drug-resistant seizures in the Dravet syndrome, N. Engl. J. Med. 376 (21) (2017) 2011-2020.

[152] O. Devinsky, A.D. Patel, J.H. Cross, V. Villanueva, E.C. Wirrell, M. Privitera, S.M. Greenwood, C. Roberts, D. Checketts, K.E. Van Landingham, S.M. Zuberi, GWPCARE3 Study Group, Effect of cannabidiol on drop seizures in the LennoxGastaut Syndrome, N. Engl. J. Med. 378 (20) (2018) 1888-1897.

[153] C.J. Naranjo, A.L. Osborne, K. Weston-Greene, Effect of cannabidiol on muscarinic neurotransmission in the pre-frontal cortex and hippocampus of the poly I:C rat model of schizophrenia, Prog. Neuro-Psychopharmacol. Behav. Psychiatry 94 (2019) 109640. 